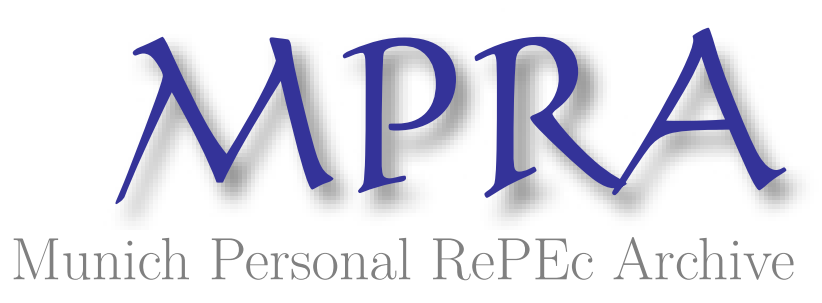

\title{
Product Market Predatory Threats and the Use of Performance-sensitive Debt
}

Kjenstad, Einar and Su, Xunhua

Norwegian University of Science and Technology

October 2012

Online at https://mpra.ub. uni-muenchen.de/44114/

MPRA Paper No. 44114, posted 03 Feb 2013 00:32 UTC 


\title{
Product Market Predatory Threats and the Use of
}

\section{Performance-sensitive Debt*}

\author{
Einar C. Kjenstad ${ }^{\dagger} \quad$ Xunhua Su $u^{\ddagger}$
}

\begin{abstract}
We use a variant of the Hotelling (1929) model to illustrate that, when a firm faces hard payment constraint(s), financially strong rivals may adopt predatory strategies to drive the firm out of the product market and hence to obtain extra profit from enhanced market power later on. Predation is more likely to occur if the payment constraint is contingent on the firm's performance. The model predicts that higher predatory threats in the product market reduce firm's use of performance-sensitive debt and this effect should be more pronounced for small firms with large growth opportunities. Through a sample of over 16,000 bank loans to U.S. borrowers in 1997-2008, we find empirical evidence to support these model predictions.
\end{abstract}

Keywords: Financial constraints, PSD, Competition, Hotelling model, HHI

${ }^{*}$ First draft, Oct. 2012; this version, Jan. 2013. We would like to thank Daniel Chi, Toni Whited and the seminar participants at University of Rochester and Norwegian University of Science and Technology for helpful comments and suggestions. Einar acknowledges financial support from the Norwegian Finance Initiative (NFI).

†Simon Graduate School of Business, University of Rochester. einar.kjenstad@simon.rochester.edu.

${ }^{\ddagger}$ Department of Economics, Norwegian University of Science and Technology. xunhua.su@svt.ntnu.no. 


\section{Introduction}

Predatory threats (or predation risk) in the product market can significantly shape a firm's financial policies. Recent empirical studies find that higher predatory threats lead to higher level of cash holdings, lower dividend payments, and more hedging (e.g., Haushalter, Klasa, and Maxwell, 2007; Hoberg, Phillips, and Prabhala, 2012). In this paper, we study how predatory threats affect firms' debt contracts. We use a a variant of the Hotelling (1929) model to show that, when a firm faces a payment constraint on which default means liquidation of the firm or termination of financing, rivals may adopt predatory strategies to drive the firm out of the product market and then to obtain extra profit through enhanced market power later on. ${ }^{1}$ This is especially the case when the payment is contingent on the firm's performance. The possibility and profit of predation are monotonically increasing in the product similarity between the prey and the predator and in the growth opportunities of the product market. We further find empirical evidence on the use of performance-sensitive debt (PSD) to support these model predictions.

In our theoretical model, two firms compete in a Hotelling line where consumers are evenly distributed. There are two periods. In each period, each consumer chooses whether to consume one unit of product from one of the two firms. By consumption, the consumer obtains a utility $U$, but have to pay the price charged by the supplier and the transportation cost, which is equal to her distance from the supplier. When there is no payment constraint at the end of the first period, the optimal strategies of the two firms are period-independent because no one can prey to drive the other out of the market. However, when one firm faces a hard payment constraint but the other does not, predation may occur. By preying and driving the constrained firm out of the market, the predator can obtain the monopolist profit

\footnotetext{
${ }^{1}$ In practice, one of the most frequently discussed predatory strategies is predatory pricing. According to OECD (2005), predatory pricing is the practice of offering goods or services at exceptionally low prices, thereby forfeiting some profit in order to drive competitors out of the market, discipline them, and/or deter entry. Generally speaking, pricing is considered predatory when it cannot be profitable unless competition is eliminated or at least restrained.
} 
in the second period. This is true especially when the payment is contingent on the firm's early performance, because a performance-sensitive payment allows the predator to strategically increase the prey's payment constraint by worsening its performance. Furthermore, predation is more likely to occur if the two firms' products are more similar. In this case, the prey's performance is more sensitive to the predator's predatory strategies. Predation is also more likely to occur when the product market has larger growth opportunities, because growth opportunities increase the monopolist's profit in the second period and hence make predation more profitable.

In practice, performance pricing in bank loans has become increasingly popular in the past two decades. A traditional bank loan before its maturity is priced using a fixed interest spread over a floating benchmark such as LIBOR or prime. Performance pricing instead has a spread based on the measures of the borrower's performance such as credit rating or debt-to-EBITDA ratio. As our model predicts, performance-sensitive payment constraints are easy to be taken advantage of by financially strong rivals, so firms that are subject to predation, e.g. small firms, should manage predation risk by using less PSD. Our model thus has two main predictions. First, the higher predatory threats that a firm is facing in the product market, the less likely the firm is to have performance-sensitive feature in its debt contracts. Second, this effect from predatory threats should be more pronounced for small firms with large growth opportunities.

We empirically test these model predictions using a sample of over 16,000 bank loans to U.S. borrowers in 1997-2008. The main proxy for predatory threats is product market fluidity constructed by Hoberg, Phillips, and Prabhala (2012), which captures the similarity between a firm's product characteristics and the comparable evolution of its rivals. We find that for small firms, fluidity is significantly related to the use of PSD, after controlling for a variety of control variables including profitability, leverage and cash flow risk, as well as industry and year dummies. A one-standard-deviation increase of fluidity is associated with a reduction in the probability of the bank loan contract having the performance-sensitive feature by $10 \%$, 
compared to the sample average (0.34). This effect from fluidity is mainly driven by firms with large growth opportunities, those having positive research and development (R\&D) spending. We also use the dummy for single-segmented firms as another proxy for predatory threats. Intuitively, a multi-segmented firm is less likely subject to predation because its product markets and investment opportunities are diversified. We find that all else equal, a single-segmented small firm on average uses PSD $53 \%$ less often than a multi-segmented small firm. These findings support our model predictions. In the literature, it is reported that firms with higher fluidity (Hoberg, Phillips, and Prabhala, 2012) and more diversified firms (Opler, Pinkowitz, Stulz, and Williamson, 1999; Duchin, 2010) hold more cash. This is consistent with our findings since firms with higher product market threats may both increase cash holdings and reduce the use of payment constraints that are subject to predation risk. ${ }^{2}$

The payment constraint in our model can be any kind of predation-inducing contractual constraints, e.g. those included in contracts with financiers, suppliers, buyers, employees or any other stakeholders. The notion of contract applies to any implicit contract between two or more parties. For example, Bertrand (2004) find that product market competition has influence on employment contracts. In addition, the constraint is not necessarily stringent and predatory strategies do not necessarily aim to drive the prey out of the market. Predation may occur so long as it increases the business risk of the prey, not only the risk to exit but also the risk of being unable to fully exploit her future investment opportunities, and hence enhances the competitive advantage of the predator. For example, dividend payments are not a binding constraint, but the stock price of a firm usually decreases significantly following a reduction in dividend payments, especially for dividend omissions (see e.g., DeAngelo, DeAngelo, and Skinner, 2008). Predation that reduces the prey's dividend payment may also worsen her performance both in the stock market and in the product market.

\footnotetext{
${ }^{2}$ Opler, Pinkowitz, Stulz, and Williamson (1999) and Duchin (2010) interpret the negative correlation between corporate diversification and cash holdings as that diversified firms are well positioned to smooth investment opportunities and cash flows because both the opportunities and the outcomes of their divisions are not perfectly correlated. That is, cash flow risk induces the correlation. We instead provide a complementary explanation that the correlation can be due to predation risk.
} 
There is a free-rider problem of predation. If the predator has to share the benefit from predation with other competitors or free-riders, predation is less likely to occur. This indicates that having more competitors in the product market does not necessarily mean higher predatory threats. Traditional competitive economic theory does not consider predation and predicts that the level of product market competition is increasing with the number of competitors. For this reason, market concentration, proxied by the Herfindahl-Hirschman Index (HHI), is frequently used as a measure of competition. A higher HHI indicates a lower level of competition (see e.g., Valta, 2012). However, we illustrates that, under certain market structures, a larger number of competitors may reduce the chances of predation and hence reduce the intensity of competition, if the predator has to share the profit from predation with more competitors or free-riders. In this sense, HHI is not an adequate measure of competition when predation is considered as one dimension of competition. The key point here is that HHI as an industry-level measure cannot fully capture the dynamic interactions between firms within the industry. In our sample, HHI has no consistently significant empirical relationship with the use of PSD.

The paper makes two main contributions to the literature. First, we contribute to the intensive literature that studies the interactions between product market competition and firm's financial policies (e.g., Brander and Lewis, 1986; Bolton and Scharfstein, 1990). Bolton and Scharfstein (1990) show that a firm with hard financial constraints, which emerge endogenously due to agency problems, could be subject to predation. Our model extends the Bolton and Scharfstein (1990) idea by showing that the possibility and profit of predation are monotonically increasing in the product similarity between the prey and the predator, and in the growth opportunities of the product market. This is consistent with Froot, Scharfstein, and Stein (1993) in that predation risk is mainly driven by the interdependence of a firms investment opportunities with that of its rivals. Several recent papers study how product market competition affects a firm's financial policy. For example, Haushalter, Klasa, and Maxwell (2007) and Hoberg, Phillips, and Prabhala (2012) report that higher predatory threats in- 
duce firms to adopt hedging strategies, hold more cash, pay less dividends, etc. It is also documented that product market competition raises the cost of debt (Valta, 2012) and the value of cash holdings (e.g., Chi and $\mathrm{Su}, 2013$ ), while large cash reserves lead to systematic future market share gains at the expenses of industry rivals (Fresard, 2010). On the one hand, firms can mitigate predation risk by both reducing predation-inducing constraints in their contracts and increasing cash holdings or hedging. On the other hand, firms can hold more cash to prey on financially weak rivals and to earn more market share. Therefore, our findings are complementary to and consistent with these previous empirical studies.

We also contribute to the literature analyzing loan contracts, especially on the use of PSD. It is documented that the use of PSD is related to prepayment probability and refinancing costs (Asquith, Beatty, and Weber, 2005), credit rating (Manso, Strulovici, and Tchistyi, 2010), corporate board structure (Francis, Hansan, Koetter, and Wu, 2012), etc. Complementary to these findings, we show that the use of PSD also takes product market threats into account. This adds a new dimension to think about firms' debt policies.

The remainder of the paper is organized as follows. In section 2, we construct the model and illustrate how payment constraints of a firm may induce predation by rivals and how PSD eases predation. Section 3 discusses the free-rider problem of predation. Section 4 provides empirical evidence. Finally, section 5 concludes.

\section{Payment Constraints and Predation}

\subsection{Model Setup}

We consider product market interactions between two rival firms, firm A and firm B. There are two periods and three dates, denoted as date 0,1 and 2 respectively. Let the product market be characterized by a Hotelling (1929) line, on which consumers are evenly distributed with density, 1 and $g$, in the two periods respectively. The parameter, $g$, measures the growth opportunities of the market. Firms are suppliers and are also located on the line. In every 
period, each consumer chooses whether or not to consume one unit of product from one firm. If consumption occurs, the consumer obtains a utility, $U$, but has to pay a transportation cost, or fit cost, equal to her distance from the supplying firm.

Without loss of generality, we assume that firm A lies to the left of firm B and the distance between them is $\alpha$. We can think of $\alpha$ as an indicator of product similarity between the two firms. The smaller $\alpha$ is, the more similar the products of the two firms are. ${ }^{3}$ At date 0 , each firm chooses a pricing strategy, consisting of the prices in the two periods, to maximize its profit. Denote the pricing strategy of firm $\mathrm{A}$ as $p_{A}^{1}$ in the first period and $p_{A}^{2}$ in the second period, and similarly that of firm $\mathrm{B}$ as $p_{B}^{1}$ and $p_{B}^{2}$. In every period, if a consumer decides to consume, she chooses the optimal supplier based on the total cost of her consumption, including the price she pays and the transportation cost. For convenience, the cost of production and the discount rates are all normalized to zero.

We further assume that firm A faces a hard payment constraint at date $1, D$, which is either an interest payment or a due face-value payment of debt, while firm B does not. This is the case when, for example, firm $\mathrm{A}$ is debt financed but firm B is equity financed. If firm A is not able to meet the constraint, it will be terminated at date 1 and then firm $\mathrm{B}$ will be the monopolist in the product market. This asymmetry of financial conditions may induce predation. ${ }^{4}$ It might be optimal for firm B to choose predatory strategies in the first period, driving firm $\mathrm{A}$ out of the market, and then to enjoy the monopolist profit in the second period.

Obviously, for sufficiently large $\alpha$, there is no product market interaction between the two firms. Each firm is a monopolist in its local market and makes its decision independently. We call such an equilibrium the "local-monopoly equilibrium", demoted as $\left(p_{A}^{1 *}, p_{B}^{1 *}\right)$ and $\left(p_{A}^{2 *}, p_{B}^{2 *}\right)$.

\footnotetext{
3 "Product" in our model refers to the physical product as well as the associated services and nonphysical value of the product. For example, both Leveno and HP produce laptops with different properties (brands, services, color, setups, etc.), but they compete in the same laptop market.

${ }^{4}$ In our model, the payment constraint is exogenously given. One may ask why firm A accepts the financial constraint if predation is possible. Bolton and Scharfstein (1990) argue that financial constraints emerge endogenously to mitigate agency problems. We adopt their result here.
} 
When $\alpha$ is below certain threshold, the two firms compete in the product market but, as long as $D$ is sufficiently small, e.g. $D=0$, predation cannot occur. We call this equilibrium without predation the "competitive equilibrium", denoted as $\left(p_{A}^{1 * *}, p_{B}^{1 * *}\right)$ and $\left(p_{A}^{2 * *}, p_{B}^{2 * *}\right)$. This is the case of the traditional competitive economic theory. Finally, predation occurs at equilibrium for sufficiently low $\alpha$ and high $D$. We call such an equilibrium the "predatory equilibrium", denoted as $\left(p_{A}^{1 * * *}, p_{B}^{1 * * *}\right)$ and $\left(p_{A}^{2 * * *}, p_{B}^{2 * * *}\right)$. In the following, the three cases of equilibria will be considered in turn.

\subsection{Local Monopoly and Competitive Equilibria}

As a starting point, consider the simplest case when the two firms are far away from each other so that they do not interact in the product market. In this case, there is no competition between them. Each firm is a monopolist in its local product market, choosing pricing strategies independently to maximize its own profit in the two periods. Concerning this local-monopoly equilibrium, we have the following proposition.

Proposition 1: The local-monopoly equilibrium, in which every firm behaves like a monopolist in its local market, occurs if and only if $\alpha \geq U$. In this case, the equilibrium pricing strategies are $p_{A}^{1 *}=p_{A}^{2 *}=p_{B}^{1 *}=p_{B}^{2 *}=\frac{1}{2} U$ and the equilibrium profits are $\Pi_{A}^{*}=\Pi_{B}^{*}=\frac{1}{2}(1+g) U^{2}$.

Proof: See Appendix.

We now consider the competitive equilibrium without predation. Following Proposition 1, when $\alpha<U$, the two firms interact with each other. To exclude predation, we first assume that $D$ is small enough. In this case, firm B is not able to drive firm A out of the market, so predation is not profitable. Decisions of the two firms are independent across periods. Given one's price in a period, the other will choose the optimal price to maximum its own profit in the same period. At equilibrium, every firm's price is the best response to the other's in each period. We now analyze such an equilibrium without predation. Define firm A's individual market as the one consisting of all consumers who earn a nonnegative surplus 
by consuming from firm A, and similarly define firm B's individual market. In the local monopoly equilibrium, the individual markets of the two firms do not overlap. We have the second proposition.

Proposition 2: When $\alpha<U$, the two firms compete at equilibrium but, as long as $D$ is sufficiently small, there is no predation. For every period s, wheres $=1$ or 2 ,

$i$ If and only if $0<\alpha<\frac{6}{7} U$, the individual markets of the two firms overlap at equilibrium. There is a unique competitive equilibrium, $p_{A}^{s * *}=p_{B}^{s * *}=\frac{1}{5}(\alpha+2 U)$, in which $\Pi_{A}^{* *}=\Pi_{B}^{* *}=\frac{3}{50}(1+g)(\alpha+2 U)^{2}$.

ii If and only if $\frac{6}{7} U \leq \alpha<U$, the individual markets of the two firms do not overlap. There are infinite number of competitive equilibria. At the symmetric equilibrium when the marginal consumer lies in the middle of the two firms, $p_{A}^{s * *}=p_{B}^{s * *}=U-\frac{1}{2} \alpha$, $\Pi_{A}^{* *}=\Pi_{B}^{* *}=\frac{1}{2}(1+g) \cdot \alpha(2 U-\alpha) .^{5}$

Proof: See Appendix.

So far, the payment constraint of firm A has been irrelevant, because it is so low that firm $\mathrm{B}$ is not able to take advantage of it and hence predation cannot occur. This is the result of the traditional Hoteling (1929) model without financial constraint. Intuitively, there is a threshold, $\bar{D}$, over which it is optimal for firm B to prey. We will solve for $\bar{D}$ in the following section.

\subsection{Payment Constraints and Predation}

In a perfect capital market, it does not matter how the firm is financed (Modigliani and Miller, 1958, 1963). With market imperfections, e.g. agency problems, usually there exists an optimal financing strategy. Bolton and Scharfstein (1990) illustrate that, when the entrepreneur is able to divert some cash flows, the optimal financial contract includes a hard payment constraint, which potentially triggers termination of financing or liquidation of the firm. This hard payment constraint aligns the firm's incentive with investors, but it induces

\footnotetext{
${ }^{5}$ The marginal consumer is defined as the one who is indifferent between consuming from the two firms.
} 
predation. Rivals may choose predatory strategies to reduce the profit of the current firm. If the current firm is not able to meet the hard payment constraint, it will be terminated and then the rivals will obtain extra profit from enhanced market power in later periods. In practice, debt is associated with hard payment constraints, on which defaults may trigger liquidation.

We take the conclusion from Bolton and Scharfstein (1990) and exogeously assume a payment constraint of firm A. Given this constraint, firm B can choose from two strategies. One is not to prey, setting the first-period price equal to that of the competitive equilibrium, $p_{B}^{1 * *}$. The other strategy is to prey by choosing a sufficiently low price in the first period, to which the best response of firm A cannot meet the payment constraint. With a predatory strategy, firm B's profit in the first period will be lower than that in the competitive equilibrium, but its profit in the second period after firm A exits will be the monopolist profit, which is higher than that in the competitive equilibrium.

Let's now solve for the threshold of the payment constraint to induce predation, $\bar{D}$. For convenience, we will focus on the simple case of $\alpha$ when there is a unique competitive equilibrium in the absence of predation, i.e. $0<\alpha \leq \frac{6}{7} U$. Predation in the case when $\frac{6}{7} U<\alpha<U$ is similar, though multiple equilibria make the analysis more complicated. In addition, when $D \geq \frac{3}{50}(\alpha+2 U)^{2}$, firm A will always go bankrupt at date 1 , no matter whether firm B preys. We thus consider only the case of $D<\frac{3}{50}(\alpha+2 U)^{2}$ in the following.

Proposition 3: When $0<\alpha \leq \frac{6}{7} U$, firm $B$ will prey if and only if $\bar{D}<D<\frac{3}{50}(\alpha+2 U)^{2}$, where the threshold of payment $\bar{D}$ satisfies:

$$
\frac{3}{50}(1+g)(\alpha+2 U)^{2}=(\sqrt{24 \bar{D}}-\alpha-2 U)\left(2 \alpha+4 U-\frac{17}{12} \sqrt{24 \bar{D}}\right)+\frac{1}{2} g U^{2} .
$$

Concerning $\bar{D}$, we have the following conclusions.

$$
\begin{aligned}
& \text { i } \partial \bar{D} / \partial \alpha>0, \partial \bar{D} / \partial g<0 \text {, and } \partial^{2} \bar{D} / \partial \alpha \partial g<0 . \\
& \text { ii If } D \geq \bar{D} \text {, there is a unique predatory equilibrium, in which } p_{A}^{1 * * *}=\frac{1}{3} \sqrt{6 D}, p_{B}^{1 * * *}=
\end{aligned}
$$




$$
\begin{aligned}
& \sqrt{24 D}-\alpha-2 U, p_{B}^{2 * * *}=\frac{1}{2} U \text {. If } D<\bar{D} \text {, predation does no occur and we have the } \\
& \text { competitive equilibrium, described in Proposition 2. }
\end{aligned}
$$

Proof: See Appendix.

The payment constraint in our model can be generalized to many kinds of constraints, for example, those included in contracts with suppliers, buyers, employees or any other stakeholders. Furthermore, the constraints are not necessarily stringent. As long as violations of the constraint cause losses for the prey, which subsequently enhance the competitive advantage of the predator, predation could occur. For example, a dividend payment is not a binding constraint, but the stock price of a firm usually decreases significantly following a reduction in dividend payment, especially for omissions (see e.g. DeAngelo, DeAngelo, and Skinner, 2008). In this case, rivals' predatory strategies may reduce the ability of the prey to maintain its dividend policy and hence induce her losses. If the prey's CEO employment depends on the stock price, predation may cause CEO shift, potentially benefiting the rivals.

If predation is observable, firm A under predation may negotiate with its counter-party who holds the claim. If negotiations can delay the payment or change the hard constraint to a soft one, predation is mitigated. However, in practice, predation is difficult to be distinguished from legitimate and vigorous price competition. ${ }^{6}$ Even if predation is present and hurts the target firm, it is difficult for outside investors to know the real reasons, management misbehaving or rival's predatory pricing, for the firms' bad performance. Even if renegotiation is possible, violations of payment constraints may cause big losses for borrowers.

\subsection{Performance-Sensitive Payment and Predation}

One of the widely observed debt features in practice is performance-sensitive payments. Manso, Strulovici, and Tchistyi (2010) report that, among bank loans to public firms in the 1995-2005 period in the Thomson Financial's SDC database, approximately 40\% include

\footnotetext{
${ }^{6}$ See, for example, the Office of the Chief Economist Discussion Paper, A Three-Step Structured Rule of Reason to Assess Predation under Article 82, by Miguel de la Mano and Benoit Durand (2005).
} 
performance-pricing provisions. Now we analyze this class of debt, which is often called performance-sensitive debt (PSD). Our main conclusion is that the use of PSD facilitates predation. Intuitively, if the payment is contingent on the firm's early performance, it is easier for rivals to worsen the performance through predatory strategies and hence to raise its payment requirement, and further to make the firm default on the higher payment requirement.

To show the point, we introduce an interim date $t$ between date 0 and date 1 , based on our model of predation in the previous section. Suppose that firm A's hard payment constraint is contingent on its date- $t$ profit, which is publicly observable. ${ }^{7}$ To simplify our analysis, we assume that the profit of firms or consumption of consumers accrues constantly overtime. That is, every consumer will consume $t$ units of the product before date $t$. Moreover, we assume that the required payment of firm $\mathrm{A}$ will be $h D$ if its accrued profit at date $t, \pi_{A}^{t}$, is no more than $t D$, while the payment is $l D$ if $\pi_{A}^{t}>t D$, where $0<l<1<h$. In our simple model, the parameters, $t, h$ and $l$, are exogenously given. But we assume that without predation, the straight debt with payment $D$ and the PSD with payments, $h D$ and $l D$, are equivalent when the contract was signed before date 0 . That is, the parameters were set such that in the absence of predation, the two debt forms are equivalent at the time when it was signed.

Let $0<\alpha<\frac{6}{7} U$ and $\bar{D}<D<\frac{3}{50 h}(\alpha+2 U)^{2}$. Namely, predation is the optimal choice of firm B as Proposition 3 shows and, in the absence of predation, firm A can meet the payment $h D$ at date 1 . If firm $\mathrm{B}$ preys but ignores the performance-sensitive property of the payment constraint that firm A faces, its total profit will be the right-hand side of (1). Now we consider a new strategy of firm B: first, firm B chooses a low price before $t$ to induce $\pi_{A}^{t} \leq t D$ and hence to raise firm A's date-1 payment to $h D$; second, firm B sets the price between date $t$ and date 1 , which drives firm $\mathrm{A}$ to default on the payment, $h D$. The two

\footnotetext{
${ }^{7}$ In practice, performance pricing is usually based on borrower's credit rating or financial ratios, e.g., debt-to-EBITDA, leverage, or interest coverage (see e.g. Asquith, Beatty, and Weber, 2005).
} 
prices does not necessarily have to be the same. The following proposition shows that this new pricing strategy increases the probability of predation.

Proposition 4: Suppose that the hard payment constraint of firm $A$ is contingent on its date-t profit $(t<1)$. The payment is $h D(h>1)$, if the accrued profit of firm $A$ at date $t$ is no more than $t D$, and is $l D$ otherwise. We have the following conclusions.

$i$ Firm $B$ will prey if and only if $D>\widehat{D}$, where

$$
\begin{aligned}
\frac{3}{50}(1+g)(\alpha+2 U)^{2}= & \frac{1}{2} g U^{2}+t \cdot(\sqrt{24 \widehat{D}}-\alpha-2 U)\left(2 \alpha+4 U-\frac{17}{12} \sqrt{24 \widehat{D}}\right) \\
& +(1-t) \cdot\left(\sqrt{24 \widehat{D} \cdot \frac{h-t}{1-t}}-\alpha-2 U\right)\left(2 \alpha+4 U-\frac{17}{12} \sqrt{24 \widehat{D} \cdot \frac{h-t}{1-t}}\right) .
\end{aligned}
$$

ii PSD eases predation, i.e., $\widehat{D}<\bar{D}$.

iii Predation is more likely to occur for lower $\alpha$, larger $g$, larger $h$ and lower $t$, i.e. $\partial \widehat{D} / \partial \alpha>0, \partial \widehat{D} / \partial g<0, \partial \widehat{D} / \partial h<0$ and $\partial \widehat{D} / \partial t<0$.

Proof: See Appendix.

The interpretation of (2) is similar to (1). The key difference is that, in the case of PSD, the first-period profit of firm B through predatory strategies includes two parts: before $t$ and after $t$. Before $t$, firm B preys to worsen firm A's performance and hence to raise firm A's date-1 payment. After $t$, firm $B$ can just set its price to maximize the profit in the current period.

\section{The Free-rider Problem of Predation}

Traditional competitive economic theory does not consider predation and predicts that the more competitors the market has, the more competitive the equilibrium is. For this reason, market concentration, proxied by the Herfindahl-Hirschman Index (HHI), is frequently used as a measure of competition. An increase in HHI generally indicates a decrease in competition and an increase of market power. In this section, we will show that, if predation is considered as one dimension of competition in the product market, HHI is no longer an adequate measure 
of competition. Predation occurs only if the predator obtains extra profit from enhanced market power after the prey exits or incurs a big loss. If there are more competitors than the predator in the product market, the predator may have to share the profit of predation with these competitors or free-riders. This dilution effect of predation due to the free-rider problem may make predation less likely to occur. Therefore, a larger number of competitors or a lower HHI of the product market may reduce the chances of predation and hence reduce the intensity of competition. HHI, as a static and backward-looking measure of market concentration and an industry-level measure of competition, cannot fully capture the dynamic interactions between firms within an industry.

To give a simple illustration for how the free-rider problem affects predation, we consider one more competitor, firm $\mathrm{C}$, in the product market. Following the analysis in section 2.3, assume $\Phi>0$ to allow for predation even in the absence of firm C. Without loss of generality, we consider only when firm B is closer to firm A than firm $\mathrm{C}$ is. This leaves us the following two cases, labeled as (I) and (II) in Figure 2. In (I), firm C is on the left-hand side of firm A and the distance between firm $\mathrm{C}$ and firm $\mathrm{A}, \beta_{\mathrm{I}}$, satisfies $\alpha \leq \beta_{\mathrm{I}}<U$. In (II), firm $\mathrm{C}$ is on the right-hand side of firm $\mathrm{B}$ and the distance between firm $\mathrm{C}$ and firm $\mathrm{B}, \beta_{\mathrm{II}}$, satisfies $0<\beta_{\text {II }}<U$.

Figure 2: Locations of Competing Firms

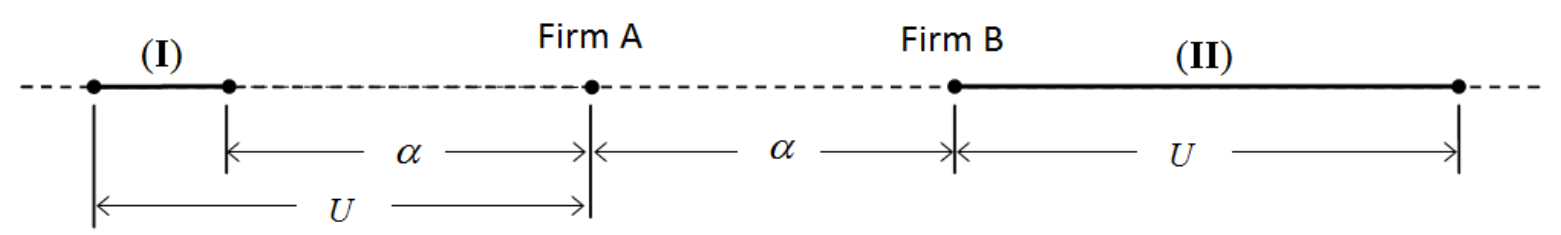

When firm $\mathrm{C}$ lies in (I), firm $\mathrm{A}$ is under competition from both firm $\mathrm{B}$ and firm $\mathrm{C}$, but the latter two compete directly only if firm A exits the market. There are two sub-cases, $\alpha+\beta_{\mathrm{I}} \geq U$ and $0 \leq \alpha+\beta_{\mathrm{I}}<U$, which we analyze in turn. First, when $\alpha+\beta_{\mathrm{I}} \geq U$, from our reasoning in section 2.3 , it is not difficult to know that the presence of firm $\mathrm{C}$ makes predation easier. This is because, as long as firm B chooses the same predatory strategy as 
that when firm $\mathrm{C}$ is absent, firm $\mathrm{A}$ will exit at date 1 and firm $\mathrm{B}$ (as well as firm $\mathrm{C}$ ) will be the monopolist in its local market in the second period. That is, no matter whether firm C preys, predation from firm B occurs at least as likely as the case when firm $\mathrm{C}$ is absent. Notice further that, under firm B's predation, firm A's profit in the presence of firm C is lower than that in the absence of firm C due to firm C's competition or co-predation. Therefore, when $\alpha+\beta_{\mathrm{I}} \geq U$, the presence of firm $\mathrm{C}$ strictly raises the probability of predation.

In the case when $0 \leq \alpha+\beta_{\mathrm{I}}<U$, it is easier for firm B to drive firm $\mathrm{A}$ out of the market at date 1 due to the closer distance between firm $\mathrm{A}$ and firm $\mathrm{C}$, but firm $\mathrm{B}$ and firm $\mathrm{C}$ have to share the post-predation profit in the second period. This dilution effect may hinder firm B's predation. From Proposition 2, if $\frac{6}{7} U \leq \alpha+\beta_{\mathrm{I}}<U$, there are multiple competitive equilibria in the second period, which complicates our analysis. We therefore, as usual, restrict our reasoning to only the symmetric equilibrium, in which the marginal consumer in the second period lies in the middle of firm B and firm C.

Lemma 1: When $0 \leq \alpha+\beta_{I}<U$, the necessary and sufficient condition for predation is $D \geq \bar{D}_{I}$, where the threshold $\bar{D}_{I}$ satisfies

$$
\begin{aligned}
\frac{1}{24}\left(23 \sqrt{D}-2 U-6 \alpha-7 \beta_{I}\right) & \left(6 U+8 \alpha+7 \beta_{I}-21 \sqrt{D}\right)+\frac{3 g}{50}\left(2 U+\alpha+\beta_{I}\right)^{2} \\
\geq & \frac{3}{2}(1+g)\left(\frac{29}{132} \alpha+\frac{7}{132} \beta_{I}+\frac{4}{11} U\right)^{2} .
\end{aligned}
$$

Proof: See Appendix.

The first part of $\widehat{\Phi}$ is firm B's profit if it preys, while the second part is firm B's profit if it does not prey. Numerically, let $\alpha=0.2, \beta_{\mathrm{I}}=0.3$ and $g=5$. If $D=0.2, \Phi>\widehat{\Phi}$, so the presence of firm $\mathrm{C}$ makes predation more difficult. If $D=0.15, \Phi<\widehat{\Phi}$. The presence of firm C makes predation easier. Similarly, we can show that, when firm C lies in (II), it is also inconclusive whether the presence of firm $\mathrm{C}$ makes it more difficult for firm B to prey. In sum, we get the following proposition. 
Proposition 5: Under certain market structures, the presence of more competitors makes predation more difficult because the predator has to share the profit from predation with other competitors or free-riders. We call this the free-rider problem of predation.

Due to the presence of financial constraints, predation could be the rational choice of some competitors in the product market. However, predation is not monotonically increasing with the number of competitors due to the free-rider problem. We show that predation is less likely to occur in certain cases when the predator has to share the benefit from predation with more competitors or free riders. Therefore, if predation is counted as one dimension of competition, market concentration or HHI is no longer an adequate measure of competition. Under certain market structures, a higher market concentration indicates a higher level of predation because the dilution effect of predation due to the free-rider problem is lower for a higher market concentration. Haushalter, Klasa, and Maxwell (2007) use HHI as a proxy for predatory threats. They interpret a higher HHI as a higher level of predatory threats or competition. From Proposition 5, we see that this may also be inappropriate, since the relationship between HHI and predation depends on specific market structures.

\section{Empirical Evidence}

\subsection{Testable Implications}

According to our theoretical model, a hard payment constraint may induce predation in the product market, especially when the payment is contingent to the target's performance. One immediate empirical implication is that among debt issuers, those who are subject to higher predatory threats should be less likely to use PSD. In addition, firm size plays a crucial role in determining rivals' predatory behavior. Consider the hypothetical example of competition between Walmart and a local independent grocery store. It is almost impossible for the local grocery store to profitably lower its price enough to prey on Walmart. Instead, we can easily imagine the opposite to occur. Our model, based on the Hotelling (1929) line, is convenient 
for studying product similarity between firms in the product space, but for simplicity we do not directly take relative firm size into account. It is possible to think of a large firm as having more locations or lower transportation costs for consumers, compared to a small firm. We expect that the effect from predatory threats on the use of PSD is significant only for small firms.

Furthermore, growth opportunities in the product market also play a role to attract predation in our model. Provided the firm is subject to predation, larger growth opportunities increase the profit from predation and are hence more likely to attract rivals to prey. We conjecture that the effect from predatory threats on the use of PSD is more pronounced for small firms with larger growth opportunities.

To sum up, our main testable hypothesis is that firms that face higher predatory threats from the product market are less likely to use PSD and the effect from predatory threats on the use of PSD is more pronounced for small firms, especially for those with larger growth opportunities.

We also identify the free-rider problem of predation. Predation may be less likely to occur if the predator has to share the benefit from predation with other rivals. Due to this freerider problem, lower market concentration, e.g. proxied by lower HHI, does not necessarily indicate a higher level of predation. We thus expect that the effect of HHI on the use of PSD is different from that of proxies for predatory threats. This motivates our use of HHI as an explanatory variable in some specifications.

\subsection{Data and Variables}

\subsubsection{Data and Sample}

We obtain loan contract data from a 2011 extract of the Reuters Loan Pricing Corporation (LPC) DealScan database, which we merge with the CRSP-Compustat merged database (quarterly Compustat data) using the DealScan-Compustat Link Data originating from 
Chava and Roberts (2008). We obtain data related to firms' product market environment, including data on HHI, industry classification and product market fluidity, from the HobergPhillips data library. ${ }^{8}$

Our sample covers the years from 1997 to 2008, for which the measure of predatory threats, fluidity, is available. There are 114,767 deal-year observations in the DealScan database for this period. Each deal, or loan, observation can consist of one or multiple facilities with different properties, e.g., revolving lines of credit, pro rata term loans or institutional term loans. We drop observations without borrower ID, total assets or fluidity information, and exclude financial firms and utilities. This results in a final unbalanced panel, consisting of 16,411 deals issued by 4,516 firms. We split the sample into two subsamples, using the following approach. For a given year, according to firms' book assets, we classify all firms in the Compustat database into two groups, "small" and "large", with equal number of firms in each group. If the borrower of a given deal in our sample in the loan activation year is classified in the "small" group in Compustat, we put this deal into the small subsample. Similarly, we get the large subsample. There are 3,746 loans issued by 1,758 firms in the small subsample and 12,665 loans issued by 2,758 firms in the large subsample. ${ }^{9}$ This indicates that our full sample consists of relatively large firms of the Compustat database, and the larger the firm is, the more often its loan issunce is. This is similar to previous studies using DealScan, which includes mostly syndicated loans issued by relatively large firms.

\subsubsection{Variable Descriptions}

The definitions of variables used in our analysis are summarized in table 1. Our main interest is to examine whether predatory threats affect the use of PSD. We construct a dummy, PSD, that equals to one for PSD and zero for non-PSD. We define a loan as PSD if it consists of at least one facility with the performance-sensitive feature, while non-PSD if it has no any

\footnotetext{
${ }^{8}$ The data is available at http://www.rhsmith.umd.edu/industrydata/.

${ }^{9}$ Since firm asset size is changing over time, it is possible that the same firm at different points in time is classified in different subgroups.
} 
facility with the performance-sensitive feature. ${ }^{10}$

Our main measure of predatory threats is product market fluidity (Fluidity) constructed in Hoberg, Phillips, and Prabhala (2012). Briefly, product market fluidity is based on firms product descriptions as found in 10-K's, utilizing rival's changes in such descriptions compared to the product description of a given firm. By definition, it is the dot product between a firm's own word usage and the comparable normalized aggregate change of the rivals. It identifies how rival's actions in terms of their product characteristics compare to a firms product characteristics in a given year. Hoberg, Phillips, and Prabhala (2012) find that higher fluidity is associated with higher cash holdings and lower dividend payment, while Chi and $\mathrm{Su}$ (2013) report that the value of cash holdings is higher for firms with higher product market fluidity. As a dynamic measure of product market interactions, fluidity captures the similarity between the firm's product change and the product evolution of its rivals. Since our model predicts that the possibility of predation is increasing in the product similarity between rivals, we think that fluidity as described above is an ideal measure of predatory threats for the empirical examination of our model predictions. A firm's product market fluidity is increasing in the product market threats that it faces.

Our second measure of predatory threats is the dummy for single-segmented firms (SingleSeg). We compute this measure using data in the Compustat Segments files. Intuitively, a multisegmented firm is subject to less predatory threats, because its product markets and investment opportunities are diversified. Opler, Pinkowitz, Stulz, and Williamson (1999) report that the number of business segments is negatively correlated with corporate cash holdings. They interpret the finding that diversified firms are more likely to have substantial assets that can be sold to finance investment opportunities, so they have lower levels of liquid assets (see also e.g., Duchin, 2010). That is, cash flow risk ot the risk to be financially constrained

\footnotetext{
${ }^{10}$ There are in general two types of PSD: interest-increasing and interest-decreasing. The former charges a higher interest rate as the borrower's performance deteriorates, while the latter charges a lower interest rate as the borrower's performance improves. Compared with the fixed-rate straight debt, both types of PSD make the payment be sensitive to performance and hence are subject to more predation risk.
} 
is the diver of the negative correlation between the number of business segments and corporate cash holdings. Alternatively, we argue that multi-segmented firms are less likely to be subject to predation risk and hence hold less cash. The cash flow risk in (Opler, Pinkowitz, Stulz, and Williamson, 1999; Duchin, 2010) and predation risk may both play important roles in determining the correlation.

We control for a number of firm characteristics in our analysis, including the natural logarithm of the book value of assets (lnAssets), cash flow risk (CashFlowRisk), investment opportunities $(Q)$, leverage (Leverage), profitability (Profitability), tangibility (Tangibility), etc. These are the commonly used explanatory variables in relevant research. ${ }^{11}$ We measure cash flow risk by the variance of EBITDA in the past eight quarters divided by the book value of assets. Firm's investment opportunities is proxied by the market-to-book ratio, calculated as the sum of the market value of equity and book value of total debt, divided by total assets. Firm leverage is the ratio of total debt to total assets, profitability is operating income before depreciation divided by total assets, and tangibility is the ratio of net PP\&E to total assets.

The loan characteristics used in our regressions include the natural logarithm of the deal amount (lnAmount) and of the loan maturity (lnMaturity), as well as dummies for loan purposes (LoanPurpose) and for whether the loan is a term loan (TermLoan) or syndicated loan (Syndication). ${ }^{12}$ These contract variables may be jointly determined with the dependent variable, inducing potential endogeneity problems (e.g., Valta, 2012). In some specifications, we eliminate all such variables.

We include year and industry dummies to control for market and industry conditions. Indus-

\footnotetext{
${ }^{11}$ Another widely-used control variable is credit rating. We do not include credit rating in our regressions because this variable has too few observations for small firms. In our sample, the 3,746 loans with 5,463 facilities issued by 1,758 small firms, only 44 have credit rating information. In addition, a dummy for credit rating in the regressions does not have influence on our results.

${ }^{12}$ Following Carey, Post, and Sharp (1998), we categorize loan purposes into four groups according to the primary purpose reported in the DealScan database: general purposes ("working capital" and "general corporate purpose"), recapitalization ("debt repayment/consolidation", "recapitalization", and "debtor-in-possession loan"), acquisition ("general or specific acquisition program" and "LBO loans") and others.
} 
try classifications are constructed by using 2-digit SIC codes or 3-digit SIC codes, depending on different specifications. We also do analyses including the TNIC HHI from Hoberg and Phillips (2011). ${ }^{13}$

\subsection{Empirical Methodology}

To test the above hypotheses, our main approach is to run Probit regressions, where the dependent variable is the dummy for PSD. The main explanatory variables include the proxy for product threats and a set of controls as follows,

$$
\operatorname{Pr}\left(Y_{i, t}=1 \mid \mathbf{X}_{i, t}\right)=\phi\left(\mathbf{X}_{i, t}^{\prime} \beta\right)
$$

where $\phi$ is the standard normal cdf; $Y_{i, t}$ is the dependent variable, taking the value of 1 if debt contract $i$ in year $t$ includes the performance-sensitive feature and 0 otherwise; and $\mathbf{X}_{i, t}$ is the set of explanatory variables. This approach is similar to the analysis on payout policy in Hoberg, Phillips, and Prabhala (2012).

Since only small firms are subject to predation, we expect that the effect from predatory threats is significant for small firms. To check whether growth opportunities play a role, we run the same regressions for small firms with large and low growth opportunities respectively. By expectation, the effects are different across these two groups.

In DealScan, the performance-sensitive feature is specified at the facility level, but our analysis is done at the loan level. ${ }^{14}$ A loan-level analysis, as opposed to facility-level analysis, is appropriate because it may be enough for the predator to take advance of the performancesensitive feature providing one facility in the loan has this feature. In addition, as Manso, Strulovici, and Tchistyi (2010) argue, because multiple facilities of the same loan cannot be treated as independent observations, a facility-level analysis produces standard errors that

\footnotetext{
${ }^{13}$ We also use the FIC-300 HHI and the fitted HHI from Hoberg and Phillips (2010a,b) to check the robustness. For more information about these industry classifications, we refer to the above cited papers as well as the Hoberg-Phillips data library.

${ }^{14} \mathrm{We}$ also check the results at the facility level (not reported in this paper). All our results are still significant.
} 
are improperly small.

Endogeneity problem may bias our results. The seemingly most common source of endogeneity in studies of financing and product market competition is the joint determination of financial policy and product market strategy. In this paper, our main measure of predatory threats is product market fluidity, which takes actions of rival firms into account. This, as Hoberg, Phillips, and Prabhala (2012) point out, mitigates the potential endogeneity issue of financial policy and product market strategy being jointly determined. We also use the dummy for single-segmented firms to measure predatory threats. It is difficult to argue that the use of PSD induces a firm to have more segments, so the endogeneity problem using this measure is not severe.

\subsection{Empirical Results}

\subsubsection{Summary Statistics}

Our full sample consists of 16,411 deals (23,108 facilities) issued by 4,516 firms. Panel A of table 2 presents summary statistics for the loans in the sample. Around $44 \%$ of the observations have the performance-sensitive feature. The mean fluidity is 6.71 and around $51 \%$ loans are issued by single-segmented firms. The mean book assets for firms in our study is 5.7 billon USD, which is larger than the Compustat average for the same years and also larger than other studies using the DealScan database (e.g., Valta, 2012). ${ }^{15}$ The average leverage, profitability, market-to-book ratio and tangibility are 32\%, 3\%, 1.79 and 0.32, respectively. For the loans in this sample, maturity has an average of approximately 48 months, the average loan amount is USD 423 million and $85 \%$ are syndicated. ${ }^{16}$ These variables are similar to previous studies using the DealScan data.

In panel B, we present summary statistics for loans issued by small firms. Since the loans in

\footnotetext{
${ }^{15}$ The data in our study does not represent a random drawn from the Compustat universe, but rather, as previous research using the DealScan database has shown, consists of relatively large firms. We believe this represents a strong bias against our findings, as predatory threats should be stronger for smaller firms.

${ }^{16}$ We take loan's maturity as the largest one among all facilities in the deal.
} 
our full sample are issued mainly by relatively large firms, our "small" subsample has only 3,746 loans (5,463 facilities) issued by 1,758 firms. Compared with the full sample, small firms issue loans less frequently. On average, small firms are more single-segmented (66\%) and use less PSD (34\%), but the fluidity measure has not significant difference across small and large firms. Small firms issue loans with smaller loan size, shorter maturity and less probability being syndicated. The average leverage, profitability, market-to-book ratio and tangibility are $24 \%, 1 \%, 2.00$ and 0.26 . These figures are all different from large firms in a pattern as expected.

\subsubsection{Differences in Firm and Loan Characteristics across Subsamples}

To get an initial insight on the relation between the use of PSD and predatory threats, we look at the distribution of the predatory measures, and firm and loan characteristics across groups of PSD and non-PSD based on firm size. Panel A and B of table 5 report means of the used explanatory variables in our empirical analyses for observations of small firms and large firms respectively. The table shows that PSD issuers have lower fluidity and are less likely to be single-segmented firms. This coincides with our model prediction that predatory threats reduce the use of PSD. Especially, the differences are more pronounced for small firms, indicating that predatory threats have more significant effects on small firms. PSD issuers also have lower market-to-book ratios than non-PSD issuers, indicating that firms with larger growth opportunities use less PSD. The effect is also more pronounced for small firms, consistent with our model predictions.

For both small and large firms, PSD loans have larger loan size and longer maturity, and are more likely to be syndicated than non-PSD loans, while PSD issuers are more profitable than non-PSD issuers. However, the difference in most of the other firm and loan characteristics across PSD and non-PSD observations are either insignificant or inconsistent for small and large firms. For example, for small firms, PSD issuers have larger asset size than non-PSD issuers, but this is in an opposite direction for large firms. Leverage, tangibility and HHI 
have similar patterns. The divergence can be explained by the argument that small and large firms face different product market threats and hence consider different factors in using PSD.

\subsubsection{Predatory Threats and the Use of PSD}

As our model predicts, predatory threats reduce the use of PSD. We examine this effect through cross-sectional Probit regressions, where the dependent variable is the dummy for PSD. Table 6 shows the results. The measure of predatory threats is Fluidity in column (1)-(5) and SingleSeg in column (6)-(10). In all regressions, standard errors are clustered at the firm level and are corrected for heteroskedasticity. We see from the table that the coefficients of both Fluidity and SingleSeg are significantly negative for small firms, indicating higher predatory threats reduces the use of PSD for firms that are subject to predation risk. However, as we analyze earlier, large firms are unlikely to be subject to predation, so predatory threats should have little effect on the use of PSD for large firms. This is confirmed by regression results using the sample of large firms in column (3), (5), (8) and (10), in which our measures of predatory threats do not show much significance. Conditional on the presence of predation risk, asset size can also be thought of as a proxy for predatory threats. In column (2) as well as (7), asset size has a significantly positive coefficient, showing that among firms that are subject to predation, a smaller asset size or higher predatory threats is associated with less use of PSD. However, in column (3) as well as (8), the use of PSD for large firms is increasing in asset size of the firm.

In particular, from column (2) or (4) of the table, a one-standard-deviation increase of fluidity is associated with a reduction in the probability of the bank loan contract to have the performance-sensitive feature by about $10 \%$, compared to the sample average (0.34). In column (7) or (9), changing from a multiple-segmented firm to a single-segmented one, the use of PSD is reduced approximately by $51 \%$. These empirical results show that firms that

face higher predatory threats from the product market are less likely to use PSD and the effect from predatory threats is more pronounced for small firms. The results are significant 
both statistically and economically, confirming our hypothesis.

Some control variables are also significantly related to the use of PSD. Profitability when included always has a significantly positive coefficient across samples and specifications. Cash flow risk has a negative effect, but significant only for small firms. This is possibly because PSD leads to early default when performance deteriorates, so borrowers with higher cash flow volatility reduce the use of PSD to reduce the probability of default. In column (3)-(5) and (8)-(10), higher leverage is associated with significantly less use of PSD. This is consistent with our model predictions, since high-leveraged firms are more possible to be subject to predation. In addition, syndicated loans and loans with longer maturity or larger amount use PSD more often. Syndicated loans have multiple lenders and more complicated structure, and hence higher refinancing costs (Bolton and Scharfstein, 1996), while longer term loans are more possible to be prepaid. Therefore, the more use of PSD among syndications and longer term loans coincides with the findings in Asquith, Beatty, and Weber (2005) that PSD is more common when prepayment is more likely or costly. Finally, it seems that the relationship between bankruptcy probability (ZScore) and the use of PSD is weak.

\subsubsection{Growth Opportunities}

According to our model predictions, predation is more likely the case in market with large growth opportunities, which raise the predator's profit after a successful predation strategy. This coincides with Froot, Scharfstein, and Stein (1993) in that predation risk is mainly driven by the interdependence of a firm's investment opportunities with those of rivals. In table 6, growth opportunities seems to have weakly negative influence on the use of PSD. Manso, Strulovici, and Tchistyi (2010) argue for the signally role of PSD for high growth firms. According their model, high growth firms should use PSD more commonly. This is not consistent with our results, because $Q$ in our regressions is a measure of observed growth opportunities, while the Manso, Strulovici, and Tchistyi (2010) signaling model considers hidden growth opportunities. 
In table 7 , we investigate how the significance of fluidity for small firms depends on their growth opportunities, which is measured by research and development (R\&D). We split small firms into two groups: those with high growth opportunities, which have positive R\&D, and those with low growth opportunities. We run the same regressions on both groups. The table shows that the effect from fluidity on the use of PSD is mainly driven by firms with high growth opportunities. Fluidity has a significantly negative effect only for small firms with positive R\&D. This is consistent with Hypothesis II.

\subsubsection{Controlling for Market Concentration}

In the literature, market concentration or HHI is widely used as the measure for product market competition. More concentrated markets are typically considered as less competitive markets. However, Kovenock and Phillips (1997) show that strategic interactions are more prevalent in more concentrated markets. Haushalter, Klasa, and Maxwell (2007) then use market concentration as a proxy for predatory threats, with more concentrated markets being considered to have higher predatory threats. We propose the free-rider problem of predation, which indicates that market concentration (HHI) may capture only the dimension of product market competition which is different from predatory threats (fluidity). To exclude the effects from market concentration, we include the TNIC HHI in our regressions. ${ }^{17}$ The results are shown in table 8. The effect from predatory threats keeps significant after controlling for HHI. $\mathrm{HHI}$ in general is not significantly related to the use of PSD. These findings are consistent with our argument on the free-rider problem of predation.

\subsubsection{Further Robustness Checks}

We have pursued a number of further robustness checks. First, some empirical studies control for industry fixed effects based on 2-digit SIC codes (e.g., Valta, 2012). We thus use industry dummies based on the 3-digit SIC codes instead of the 2-digit SIC codes. Table 9 shows

\footnotetext{
${ }^{17}$ We also use the FIC-300 HHI and the fitted HHI to run these regressions (results not reported here), but the conclusions are the same.
} 
that our results are not sensitive to industry classifications. Second, our results are not driven by the econometric models used. We consider linear probability models (LPM) in table 10 instead of the Probit models, and obtain qualitatively similar results. Third, we do our analysis on the facility level in table 11. Our full sample consists of 16,411 loans with 23,108 facilities, while the small-firm subsample consists of 3,746 loans with 5,463 facilities. The table shows no any significant change in our results. To sum up, the conclusions draw previously are robust to these checks.

\section{Conclusion}

In the literature, it is argued that PSD is used to mitigate agency problems (e.g., Manso, Strulovici, and Tchistyi, 2010) or to save refinancing costs (e.g., Asquith, Beatty, and Weber, 2005). This paper through a variant of the Hotelling (1929) model illustrates that the use of PSD may facilitates predation. For firms facing higher predatory threats, to mitigate the predation risk, their debt contracts should be less likely to have the performance-sensitive feature. We provide empirical evidence supporting these model predictions. In particular, small firms with large growth opportunities and higher predatory threats are less likely to use PSD. This is consistent with Haushalter, Klasa, and Maxwell (2007) and Hoberg, Phillips, and Prabhala (2012) in that higher predatory threats are associated with larger cash holding, more hedging and lower payout ratios. Our results suggest in a different angle from previous researches that product market considerations are important in designing debt contracts and understanding firm's financial policies.

\section{References}

Asquith, P., A. Beatty, J. Weber, 2005. Performance Pricing in Bank Debt Contracts. Journal of Accounting and Economics 40, 101-128.

Bertrand, M., 2004. From the Invisible Handshake to the Invisible Hand? How Import 
Competition Changes the Employment Relationship. Journal of Labor Economics 22, 723765.

Bolton, P., D. S. Scharfstein, 1990. A Theory of Predation Based on Agency Problems in Financial Contracting. American Economic Review 80, 93-106.

Bolton, P., D. S. Scharfstein, 1996. Optimal Debt Structure and the Number of Creditors. Journal of Political Economy 104, 1-25.

Brander, J., T. Lewis, 1986. Oligopoly and Financial Structure: The Limited Liability Effect. American Economic Review 76, 956-970.

Carey, M., M. Post, S. A. Sharp, 1998. Does Corporate Lending by Banks and Finance Companies Differ? Evidence on Specialization in Private Debt Contracting. Journal of Finance 53, 845-878.

Chava, S., M. R. Roberts, 2008. How Does Financing Impact Investment?. Journal of Finance 63, 2085-2121.

Chi, D. J., X. Su, 2013. Product Market Predatory Threats and the Value of Cash Holdings. Working Paper pp. 1-47.

DeAngelo, H., L. DeAngelo, D. J. Skinner, 2008. Corporate Payout Policy. Foundations and Trends in Finance 3, 95-287.

Duchin, R., 2010. Cash Holdings and Corporate Diversification. Journal of Finance 65, 955992.

Francis, B., I. Hansan, M. Koetter, Q. Wu, 2012. Corporate Board and Bank Loan Contracting. Jouranl of Financial Research 35, 521-552.

Fresard, L., 2010. Financial strength and product market behavior: The real effects of corporate cash holdings. Journal of Finance 65, 1097-1122.

Froot, K. A., D. S. Scharfstein, J. C. Stein, 1993. Risk management: coordinating corporate investment and financing policies. Journal of Finance 48, 1629-1658. 
Haushalter, D., S. Klasa, W. F. Maxwell, 2007. The influence of product market dynamics on a firm's cash holdings and hedging behavior. Journal of Financial Economics 84, 797-825.

Hoberg, G., G. Phillips, 2010a. Product Market Synergies and Competition in Mergers and Acquisitions: A Text-Based Analysis. Review of Financial Studies 23, 3773-3811.

, 2010b. Real and Financial Industry Booms and Busts. Journal of Finance 65, 45-86.

— , 2011. Text-Based Network Industries and Endogenous Product Differentiation. University of Maryland Working Paper pp. 1-50.

Hoberg, G., G. Phillips, N. Prabhala, 2012. Product Market Threats, Payouts, and Financial Flexibility. Forthcoming, Journal of Finance.

Hotelling, H., 1929. Stability in Competition. Economic Journal 39, 41-57.

Kovenock, D., G. M. Phillips, 1997. Capital Structure and Product Market Behavior: An Examination of Plant Exit and Investment Decisions. Review of Financial Studies 10, $767-803$.

Manso, G., B. Strulovici, A. Tchistyi, 2010. Performance-Sensitive Debt. Review of Financial Studies 23, 1819-1854.

McFadden, D., 1974. Conditional Logit Analysis of Qualitative Choice Behavior. In P. Zarembka (ed.), Frontiers in Econometrics, New York: Academic Press.

Modigliani, F., M. H. Miller, 1958. The Cost of Capital, Corporate Finance and the Theory of Investment. American Economic Review 48, 261-297.

— 1963. Corporate Income Taxes and the Cost of Capital: A Correction. American Economic Review 53, 433-443.

OECD, 2005. Preserving Competition: Keeping Predators at Bay. Policy Brief, OECD pp. 1-6. Available at www.oecd.org/dataoecd/59/20/35871625.pdf.

Opler, T., L. Pinkowitz, R. Stulz, R. Williamson, 1999. The determinants and implications of corporate cash holdings. Journal of Financial Economics 52, 3-46. 
Valta, P., 2012. Competition and the cost of debt. Journal of Financial Economics 105, $661-682$.

\section{Appendix}

\section{Proof of Proposition 1}

The optimization problem of firm $\mathrm{A}$ is $\max _{\left(p_{A}^{1}, p_{A}^{2}\right)} \Pi_{A}=2 p_{A}^{1}\left(U-p_{A}^{1}\right)+2 g \cdot p_{A}^{2}\left(U-p_{A}^{2}\right)$. This problem has a unique solution, $p_{A}^{1 *}=p_{A}^{2 *}=\frac{1}{2} U$ and $\Pi_{A}^{*}=U^{2}$. Similarly, $p_{B}^{1 *}=p_{B}^{2 *}=\frac{1}{2} U$ and $\Pi_{B}^{*}=U^{2}$. This is the maximum profit that a firm is able to obtain. If $\alpha \geq U$, obviously the two firms will set their prices to $\frac{1}{2} U$ and both earn $U^{2}$. No one has incentive to deviate. Therfore, if $\alpha \geq U, p_{B}^{1 *}=p_{B}^{2 *}=\frac{1}{2} U$.

Now we show that, if $p_{A}^{1 *}=p_{A}^{2 *}=p_{B}^{1 *}=p_{B}^{2 *}=\frac{1}{2} U, \alpha \geq U$. The proof is by contradiction. Suppose $p_{A}^{1 *}=p_{A}^{2 *}=p_{B}^{1 *}=p_{B}^{2 *}=\frac{1}{2} U$ but $\alpha<U$. Obviously, the decisions of the firms are independent across periods, so we only consider the first period. Without loss of generality, let firm B stick to $p_{B}^{1 *}=\frac{1}{2} U$ and consider a price deviation of firm A to $\frac{1}{2} U-\epsilon$, where $\epsilon$ is a small and positive number. Given that $\epsilon$ is a small enough, there is a marginal consumer who is indifferent between consuming form firm $\mathrm{A}$ and from firm B. Let $x$ be the distance between this marginal consumer and firm A. We have $U-x-\left(\frac{1}{2} U-\epsilon\right)=U-(\alpha-x)-\frac{1}{2} U$ or $x=\frac{1}{2}(\alpha+\epsilon)$. The profit of firm A changes to

$$
\pi_{A}^{1}=\left(\frac{1}{2} U-\epsilon\right)\left[\frac{1}{2}(\alpha+\epsilon)+\left(\frac{1}{2} U+\epsilon\right)\right]=\left(\frac{1}{2} U-\epsilon\right)\left(\frac{1}{2} U+\frac{1}{2} \alpha+\frac{3}{2} \epsilon\right)
$$

FOC: $\epsilon=\frac{1}{12}(U-2 \alpha)$. That is, if $\alpha<U$, firm A can deviate its price from $\frac{1}{2} U$ to $\frac{7}{12} U-\frac{1}{6} \alpha$ and earn a higher profit. This contradicts with $p_{A}^{1 *}=\frac{1}{2} U$.

Q.E.D.

\section{Proof of Proposition 2-i}

Note that, for any pricing strategies $\left(p_{A}^{1}, p_{B}^{1}\right)$, the consumer who earns zero surplus by consuming the product from firm A lies $U-p_{A}^{1}$ away from firm A, while the one who earns zero surplus by consuming the product from firm B lies $U-p_{B}^{1}$ away from firm $\mathrm{B}$. Therefore, if the individual markets of the two firms overlap at equilibrium, $\left(U-p_{A}^{1}\right)+\left(U-p_{B}^{1}\right)<\alpha$ or $p_{A}^{1}+p_{B}^{1} \geq 2 U-\alpha$. In this case, there are two possibilities concerning the location of the 
marginal consumer. Either the marginal consumer lies in between the two firms, or she does not. We first exclude the second possibility as an equilibrium. The proof is by contradiction. Without loss of generality, suppose that at equilibrium, the marginal consumer lies on the left-hand side of firm A. Denote the distance between the marginal consumer and firm A as $x$. We have $U-x-p_{A}^{1 * *}=U-(\alpha+x)-p_{B}^{1 * *}$ or $p_{A}^{1 * *}=\alpha+p_{B}^{1 * *}$, which indicates that all consumers on the left-hand side of firm $\mathrm{A}$ is indifferent between consuming from the two firms. That is, all these consumers are marginal consumers. In this case, suppose that a proportion $\gamma$ of marginal consumers will choose firm A, where $0<\gamma<1$. In this case, $\pi_{A}^{1 * *}=\gamma p_{A}^{1 * *}\left(U-p_{A}^{1 * *}\right)$. If firm A decreases its price, $p_{B}^{1 * *}+\alpha$, by an infinitely small amount $\delta$, firm A will get all the consumers on its left-hand side and its profit will be larger than $p_{A}^{1 * *}\left(U-p_{A}^{1 * *}\right)$. That is, the marginal profit for firm A by increasing its price is positively infinite. Therefore, at equilibrium it is impossible to have $p_{A}^{1 * *}=\alpha+p_{B}^{1 * *}$. We get contradiction, so the marginal consumer cannot lie on the same side of the two firms.

Denote the distance between the marginal consumer and firm $\mathrm{A}$ as $x$. For given pricing strategies $\left(p_{A}^{1}, p_{B}^{1}\right), U-x-p_{A}^{1}=U-(\alpha-x)-p_{B}^{1}$ or $x=\frac{1}{2}\left(\alpha+p_{B}^{1}-p_{A}^{1}\right)$. The profit of firm $\mathrm{A}$ is $\pi_{A}^{1}=p_{A}^{1}\left[\frac{1}{2}\left(\alpha+p_{B}^{1}-p_{A}^{1}\right)+\left(U-p_{A}^{1}\right)\right]$. The optimization problem of firm $\mathrm{A}$, for any given pricing strategy of firm $\mathrm{B}$, is

$$
\max _{p_{A}^{1}} \pi_{A}^{1}=\frac{1}{2} p_{A}^{1}\left(2 U+\alpha-3 p_{A}^{1}+p_{B}^{1}\right)
$$

FOC: $p_{A}^{1}=\frac{1}{6}\left(\alpha+2 U+p_{B}^{1}\right)$. This is the best response of firm A to any $p_{B}^{1}$. Similarly, the best response of firm $\mathrm{B}$ to any $p_{A}^{1}$ is $p_{B}^{1}=\frac{1}{6}\left(\alpha+2 U+p_{A}^{1}\right)$. Combining both response functions, we get $p_{A}^{1 * *}=p_{B}^{1 * *}=\frac{1}{5}(\alpha+2 U)$ and $\pi_{A}^{1 * *}=\pi_{B}^{1 * *}=\frac{3}{50}(\alpha+2 U)^{2}$. Since $p_{A}^{1}+p_{B}^{1} \geq 2 U-\alpha$, we have $\alpha<\frac{6}{7} U$.

Q.E.D.

\section{Proof of Proposition 2-ii}

From the proof for proposition 2 -i, we know that, if and only if $p_{A}^{1}+p_{B}^{1} \geq 2 U-\alpha$, the individual markets of the two firms do not overlap. However, if $p_{A}^{1}+p_{B}^{1}>2 U-\alpha>U$ (since $\alpha<U)$, the price of at least one firm is larger than $\frac{1}{2} U$. Because the profit function in price is quadratic and obtains the global maximum at $\frac{1}{2} U$, this firm can raise its own profit by reducing its price closer to $\frac{1}{2} U$ by a small positive amount, with which the individual markets 
still have no overlap. Thus, when the individual markets do not overlap at equilibrium and $\alpha<U$, there must be $p_{A}^{1 * *}+p_{B}^{1 * *}=2 U-\alpha$. In this case, the marginal consumer, who is indifferent between firm $\mathrm{A}$ and firm $\mathrm{B}$, lies $U-p_{A}^{1 * *}$ away from firm $\mathrm{A}$ and $U-p_{B}^{1 * *}$ away from firm B. At the symmetric equilibrium when the marginal consumer lies in the middle of the two firms, $p_{A}^{s * *}=p_{B}^{s * *}=U-\frac{1}{2} \alpha, \Pi_{A}^{* *}=\Pi_{B}^{* *}=\frac{1}{2}(1+g) \cdot \alpha(2 U-\alpha)$.

Given $p_{A}^{1 * *}+p_{B}^{1 * *}=2 U-\alpha$ and $\alpha<U$, if $p_{A}^{1 * *}<\frac{1}{2} U$, firm A can increase this price to $\frac{1}{2} U$. Such an increase keeps the individual markets un-overlaped while it raises firm A's profit. This contradicts with $p_{A}^{1 * *}$ being the equilibrium price. Therefore, $p_{A}^{1 * *} \geq \frac{1}{2} U$ and $p_{B}^{1 * *} \geq \frac{1}{2} U$. It follows that $p_{A}^{1 * *}=2 U-\alpha-p_{B}^{1 * *} \leq 2 U-\alpha-\frac{1}{2} U=\frac{3}{2} U-\alpha$. In sum, $p_{A}^{1 * *} \in\left[\frac{1}{2} U, \frac{3}{2} U-\alpha\right]$ and similarly $p_{B}^{1 * *} \in\left[\frac{1}{2} U, \frac{3}{2} U-\alpha\right]$. Given that $p_{A}^{1 * *}, p_{B}^{1 * *} \in\left[\frac{1}{2} U, \frac{3}{2} U-\alpha\right]$ and $p_{A}^{1 * *}+p_{B}^{1 * *}=2 U-\alpha$, consider whether the firms have incentives to deviate. Obviously, neither firm has incentive to increase the price because this reduces its own profit. Therefore, the only profitable deviation is to reduce the price. Without loss of generality, suppose that firm A reduces the price by a small positive amount $\epsilon$ while firm B keeps $p_{B}^{1 * *}$. Because of the lower price of firm $\mathrm{A}, p_{A}^{1 * *}-\epsilon$, there is market overlap now and the marginal borrower is closer to firm $\mathrm{B}$ than before. Let $x$ be the distance between this marginal consumer and firm A. We have $U-x-\left(p_{A}^{1 * *}-\epsilon\right)=U-(\alpha-x)-p_{B}^{1 * *}$ or $x=\frac{1}{2}\left(\alpha+p_{B}^{1 * *}-p_{A}^{1 * *}+\epsilon\right)$. The profit of firm A is

$$
\begin{aligned}
\pi_{A}^{1} & =\left(p_{A}^{1 * *}-\epsilon\right)\left[\frac{1}{2}\left(\alpha+p_{B}^{1 * *}-p_{A}^{1 * *}+\epsilon\right)+\left(U-p_{A}^{1 * *}+\epsilon\right)\right] \\
& =2\left(p_{A}^{1 * *}-\epsilon\right)\left(U-p_{A}^{1 * *}+\frac{3}{4} \epsilon\right) .
\end{aligned}
$$

$d \pi_{A}^{1} / d \epsilon=\frac{7}{2}\left(p_{A}^{1 * *}-\frac{4}{7} U\right)-3 \epsilon$. If $p_{A}^{1 * *}>\frac{4}{7} U, d \pi_{A}^{1} / d \epsilon>0$ for small enough $\epsilon$. That is, firm A can reduce $p_{A}^{1 * *}$ to raise profit. This contradicts with $p_{A}^{1 * *}$ being the equilibrium, so $p_{A}^{1 * *} \leq \frac{4}{7} U$ and $p_{B}^{1 * *} \leq \frac{4}{7} U$. It follows that $p_{A}^{1 * *}+p_{B}^{1 * *}=2 U-\alpha \leq \frac{8}{7} U$ or $\alpha \geq \frac{6}{7} U$.

Q.E.D.

\section{Proof of Proposition 3}

A predatory strategy of firm $\mathrm{B}, p_{B}^{1}$, is to reduce firm's date- 1 profit no more than $D$. When $0<\alpha \leq \frac{6}{7} U$, the best response of firm A to $p_{B}^{1}$ is $p_{A}^{1}=\frac{1}{6}\left(\alpha+2 U+p_{B}^{1}\right)$ and the profit of firm A is $\pi_{A}^{1}=\frac{1}{24}\left(2 U+\alpha+p_{B}^{1}\right)^{2}$. Therefore, the optimal predatory strategy of firm $\mathrm{B}, p_{B}^{1 * * *}$, satisfies $\frac{1}{24}\left(2 U+\alpha+p_{B}^{1 * * *}\right)^{2}=D$ or $p_{B}^{1 * * *}=\sqrt{24 D}-\alpha-2 U$. Note that, given $0<\alpha \leq U, D<\frac{3}{50}(\alpha+2 U)^{2}<\frac{1}{24}(\alpha+3 U)^{2}$, so $p_{B}^{1 * * *}<U$. For the marginal consumer, we 
have $\alpha-x=\frac{1}{2}\left(\frac{7}{6} \alpha+\frac{1}{3} U-\frac{5}{6} p_{B}^{1 * * *}\right)$. The profit of firm $\mathrm{B}$ in the first period is

$$
\pi_{B}^{1 * * *}=p_{B}^{1 * * *}\left[(\alpha-x)+\left(U-p_{B}^{1 * * *}\right)\right]=(\sqrt{24 D}-\alpha-2 U)\left(2 \alpha+4 U-\frac{17}{12} \sqrt{24 D}\right) .
$$

After firm A goes bankrupt at date 1, firm B will obtain the monopolist profit in the second period, $\pi_{B}^{2 * * *}=\frac{1}{2} g U^{2}$, so the total profit in the two periods is

$$
\Pi_{B}^{* * *}=(\sqrt{24 D}-\alpha-2 U)\left(2 \alpha+4 U-\frac{17}{12} \sqrt{24 D}\right)+\frac{1}{2} g U^{2} .
$$

Recall $\Pi_{B}^{* *}=\frac{3}{50}(1+g)(\alpha+2 U)^{2}$. We have $\Phi=\Pi_{B}^{* * *}-\Pi_{B}^{* *}, \frac{\partial \Phi}{\partial D}>0, \frac{\partial \Phi}{\partial g}>0, \frac{\partial \Phi}{\partial \alpha}<0$ and $\frac{\partial^{2} \Phi}{\partial \alpha \partial g}<0$. If $\Pi_{B}^{* *}<\Pi_{B}^{* * *}$, the optimal strategy of firm B is to prey in the first period, and $p_{A}^{1 * * *}=\frac{1}{3} \sqrt{6 D}, p_{B}^{1 * * *}=\sqrt{24 D}-\alpha-2 U, p_{B}^{2 * * *}=\frac{1}{2} U$.

Q.E.D.

\section{Proof of Proposition 4}

From Proposition 3, the optimal price before $t$ is $p_{B}^{t * * * *}=p_{B}^{1 * * *}=\sqrt{24 D}-\alpha-2 U$. With this price, firm A's profit accrued before date $t$ is exactly $t D$ and the required payment will be $h D$ at date 1 . Between date $t$ and date 1 , the optimal predatory price of firm $\mathrm{B}, p_{B}^{1 * * * *}$, should make firm A's profit within this period no more than $(h-t) D$. Note the length of this period is $1-t$. Also following the reasoning in section 2.3, we get

$$
p_{B}^{1 * * * *}=\sqrt{24 D \cdot \frac{h-t}{1-t}}-\alpha-2 U
$$

The profit of firm B in the first period includes two parts as follows

$$
\pi_{B}^{1 * * * *}=t \cdot p_{B}^{t * * * *}\left[(\alpha-x)+\left(U-p_{B}^{t * * * *}\right)\right]+(1-t) \cdot p_{B}^{1 * * * *}\left[(\alpha-x)+\left(U-p_{B}^{1 * * * *}\right)\right]
$$

Note that

$$
\begin{aligned}
\pi_{B}^{1 * * * *}-\pi_{B}^{1 * * *}=(1-t)\left[\left(\sqrt{24 D \cdot \frac{h-t}{1-t}}-\alpha-2 U\right)\left(2 \alpha+4 U-\frac{17}{12} \sqrt{24 D \cdot \frac{h-t}{1-t}}\right)\right. \\
\left.-(\sqrt{24 D}-\alpha-2 U)\left(2 \alpha+4 U-\frac{17}{12} \sqrt{24 D}\right)\right]
\end{aligned}
$$

When $D<\frac{3}{50}(\alpha+2 U)^{2}, \pi_{B}^{1 * * * *}>\pi_{B}^{1 * * *}$. That is, if the date-1 payment of firm A is contingent on its date- $t$ performance, firm $B$ through predation can obtain a higher profit than that 
when the date-1 payment of firm $\mathrm{A}$ is unconditional. ${ }^{18}$

Since $\pi_{B}^{1 * * * *}>\pi_{B}^{1 * * *}$, it is immediate to get that $\widehat{D}<\bar{D}$. We proved (i) and (ii). To prove (iii), let $y=\sqrt{24 \widehat{D}}$ and $\gamma=\sqrt{\frac{h-t}{1-t}}>1$. That is, $\widehat{D}=\frac{1}{24} y^{2}$ and $h=t+(1-t) \gamma^{2}$. Predation is necessary to make firm A default on the date-1 payment only when $\widehat{D}<\frac{3}{50 h}(\alpha+2 U)^{2}$, so we have $y<\frac{6}{5 h}(\alpha+2 U)$. From (2),

$$
\frac{d \widehat{D}}{d \alpha}=\frac{y}{12} \frac{d y}{d \alpha}=\frac{y}{12} \cdot \frac{\frac{50+3 g}{25}(\alpha+2 U)-\frac{41}{24}[t+(1-t) \gamma] y}{\frac{41}{24}(\alpha+2 U)[t+(1-t) \gamma]-\frac{34}{24}\left[t+(1-t) \gamma^{2}\right] y}>0
$$

Similarly, we can get that $\frac{d y}{d \gamma}<0$ and $\frac{d \gamma}{d h}>0$, so $\frac{d \widehat{D}}{d h}=\frac{y}{12} \frac{d y}{d \gamma} \frac{d \gamma}{d h}<0$. Comparing (1) and (2), we can easily get $\frac{d \widehat{D}}{d t}<0$ because $\pi_{B}^{1 * * * *}>\pi_{B}^{1 * * *}$.

\section{Q.E.D.}

\section{Proof of Lemma 1}

If there is no predation, each firm at equilibrium chooses the best response to the prices of the other two in every period. This is just an extension of the case in section 2.2. Suppose the marginal consumer of firm A and B lies $x$ away from firm A, while the marginal consumer of firm $\mathrm{A}$ and $\mathrm{C}$ lies $y$ away from firm $\mathrm{A}$. We have $x=\frac{1}{2}\left(p_{B}^{1}-p_{A}^{1}+\alpha\right)$ and $y=\frac{1}{2}\left(p_{C}^{1}-p_{A}^{1}+\beta_{\mathrm{I}}\right)$. The optimization problems are

$$
\begin{aligned}
& \max _{p_{A}^{1}} \pi_{A}^{1}=p_{A}^{1} \cdot(x+y)=p_{A}^{1} \cdot\left[\frac{1}{2}\left(\alpha+\beta_{\mathrm{I}}+p_{B}^{1}+p_{C}^{1}\right)-p_{A}^{1}\right] \\
& \max _{p_{B}^{1}} \pi_{B}^{1}=p_{B}^{1} \cdot\left[(\alpha-x)+\left(U-p_{B}^{1}\right)\right]=p_{B}^{1} \cdot\left(U+\frac{1}{2} \alpha+\frac{1}{2} p_{A}^{1}-\frac{3}{2} p_{B}^{1}\right) \\
& \max _{p_{C}^{1}} \pi_{C}^{1}=p_{C}^{1} \cdot\left[\left(\beta_{\mathrm{I}}-y\right)+\left(U-p_{C}^{1}\right)\right]=p_{C}^{1} \cdot\left(U+\frac{1}{2} \beta_{\mathrm{I}}+\frac{1}{2} p_{A}^{1}-\frac{3}{2} p_{C}^{1}\right)
\end{aligned}
$$

The best response functions are

$$
\left\{\begin{array}{l}
p_{A}^{1}=\frac{1}{4}\left(\alpha+\beta_{\mathrm{I}}+p_{B}^{1}+p_{C}^{1}\right) \\
p_{B}^{1}=\frac{1}{6}\left(2 U+\alpha+p_{A}^{1}\right) \\
p_{C}^{1}=\frac{1}{6}\left(2 U+\beta_{\mathrm{I}}+p_{A}^{1}\right)
\end{array}\right.
$$

Solving this equation system, we can get the optimal pricing strategies when there is no predation. All results are summarized in column 2 of the table.

\footnotetext{
${ }^{18}$ In our reasoning, it seems that $l$ does not play any role. This is not true because, as we assume earlier, $l$ in our model is used to make the two contract forms, the straight debt and the PSD, equivalent when the contract was signed.
} 
Now consider when firm B preys but firm C, as the free-rider, does not. ${ }^{19}$ In the second period when firm A exits, obviously the profits of firm B and firm C are both $\frac{3}{50} g\left(2 U+\alpha+\beta_{\mathrm{I}}\right)^{2}$. In the following, we focus on the pricing strategy in the first period. Suppose firm B chooses a pricing strategy, $p_{B}^{1}$. From (7), we have

$$
\left\{\begin{array}{l}
p_{A}^{1}=\frac{1}{23}\left(2 U+6 \alpha+7 \beta_{\mathrm{I}}+6 p_{B}^{1}\right) \\
p_{C}^{1}=\frac{1}{23}\left(8 U+\alpha+5 \beta_{\mathrm{I}}+p_{B}^{1}\right)
\end{array}\right.
$$

To prey, firm B will choose $p_{B}^{1}$ such that firm A's profit equals to $D$. That is

$$
p_{A}^{1} \cdot\left[\frac{1}{2}\left(\alpha+\beta_{\mathrm{I}}+p_{B}^{1}+p_{C}^{1}\right)-p_{A}^{1}\right]=\frac{1}{529}\left(2 U+6 \alpha+7 \beta_{\mathrm{I}}+6 p_{B}^{1}\right)^{2}=D .
$$

Thus the predatory pricing strategy of firm B equals to $\frac{23}{6} \sqrt{D}-\frac{1}{3} U-\alpha-\frac{7}{6} \beta_{\mathrm{I}}$. Given this predatory pricing strategy, the corresponding optimal strategies of firm A and firm $\mathrm{C}$ can be solved through (8) and are respectively, $\sqrt{D}$ and $\frac{1}{6}\left(\sqrt{D}+2 U+\beta_{\mathrm{I}}\right)$. We can further solve for the profits. The results are shown in column 3 of the following table.

In sum, we can get $\widehat{\Phi}$.

Equilibria when $\frac{6}{7} U \leq \alpha+\beta_{\mathbf{I}}<U$

\begin{tabular}{c|c|c}
\hline Items & No Predation & B preys but C does not. \\
\hline$p_{A}^{1}$ & $\frac{7}{22} \alpha+\frac{7}{22} \beta_{\mathrm{I}}+\frac{2}{11} U$ & $\sqrt{D}$ \\
$p_{B}^{1}$ & $\frac{29}{132} \alpha+\frac{7}{132} \beta_{\mathrm{I}}+\frac{4}{11} U$ & $\frac{23}{6} \sqrt{D}-\frac{1}{3} U-\alpha-\frac{7}{6} \beta_{\mathrm{I}}$ \\
$p_{C}^{1}$ & $\frac{7}{132} \alpha+\frac{29}{132} \beta_{\mathrm{I}}+\frac{4}{11} U$ & $\frac{1}{6}\left(\sqrt{D}+2 U+\beta_{\mathrm{I}}\right)$ \\
$\pi_{A}^{1}$ & $\left(\frac{7}{22} \alpha+\frac{7}{22} \beta_{\mathrm{I}}+\frac{2}{11} U\right)^{2}$ & $D$ \\
$\pi_{B}^{1}$ & $\frac{3}{2}\left(\frac{29}{132} \alpha+\frac{7}{132} \beta_{\mathrm{I}}+\frac{4}{11} U\right)^{2}$ & $\left(\frac{23}{6} \sqrt{D}-\frac{1}{3} U-\alpha-\frac{7}{6} \beta_{\mathrm{I}}\right)\left(\frac{3}{2} U+2 \alpha+\frac{7}{4} \beta_{\mathrm{I}}-\frac{21}{4} \sqrt{D}\right)$ \\
$\pi_{C}^{1}$ & $\frac{3}{2}\left(\frac{7}{132} \alpha+\frac{29}{132} \beta_{\mathrm{I}}+\frac{4}{11} U\right)^{2}$ & $\frac{1}{24}\left(\sqrt{D}+2 U+\beta_{\mathrm{I}}\right)^{2}$ \\
\hline$p_{A}^{2}$ & $\frac{7}{22} \alpha+\frac{7}{22} \beta_{\mathrm{I}}+\frac{2}{11} U$ & - \\
$p_{B}^{2}$ & $\frac{29}{132} \alpha+\frac{7}{132} \beta_{\mathrm{I}}+\frac{4}{11} U$ & $\frac{1}{5}\left(2 U+\alpha+\beta_{\mathrm{I}}\right)$ \\
$p_{C}^{2}$ & $\frac{7}{132} \alpha+\frac{29}{132} \beta_{\mathrm{I}}+\frac{4}{11} U$ & $\frac{1}{5}\left(2 U+\alpha+\beta_{\mathrm{I}}\right)$ \\
$\pi_{A}^{2}$ & $\left(\frac{7}{22} \alpha+\frac{7}{22} \beta_{\mathrm{I}}+\frac{2}{11} U\right)^{2}$ & - \\
$\pi_{B}^{1}$ & $\frac{3}{2}\left(\frac{29}{132} \alpha+\frac{7}{132} \beta_{\mathrm{I}}+\frac{4}{11} U\right)^{2}$ & $\frac{3}{50}\left(2 U+\alpha+\beta_{\mathrm{I}}\right)^{2}$ \\
$\pi_{C}^{1}$ & $\frac{3}{2}\left(\frac{7}{132} \alpha+\frac{29}{132} \beta_{\mathrm{I}}+\frac{4}{11} U\right)^{2}$ & $\frac{3}{50}\left(2 U+\alpha+\beta_{\mathrm{I}}\right)^{2}$ \\
\hline
\end{tabular}

${ }^{19}$ We ignore cases in which both firm B and firm C prey and in which firm B is the free-rider. 
Table 1: Variable Definitions

The table shows the notation and definition of variables used in our analysis. The variables are classified into four catagories: dependent variables, borrower characteristics, loan characteristics and market and industry characteristics.

\begin{tabular}{|c|c|}
\hline Variable & Definition \\
\hline \multicolumn{2}{|c|}{ Dependent variables } \\
\hline$P S D$ & Dummy $=1$ for performance-sensitive loans \\
\hline$P S D_{F}$ & Dummy = 1 for performance-sensitive facilities \\
\hline \multicolumn{2}{|c|}{ Borrower characteristics } \\
\hline Fluidity & Measure of product market threats based on product descriptions \\
\hline SingleSeg & Dummy $=1$ if the firm has only one business segment in the year \\
\hline $\ln$ Assets & $\begin{array}{l}\text { The natural logarithm of Total Assets measured in million U.S. dollar, } \\
\text { i.e. } \log (a t q)\end{array}$ \\
\hline $\mathrm{Q}$ & $\begin{array}{l}\text { Market value / Total Assets, i.e. }(a t q-(a t q-l t q+t x d i t c q)+(\operatorname{prccq} * \\
c s h o q)) / a t q\end{array}$ \\
\hline Leverage & Total Liabilities / Total Assets, i.e. $(d l c q+d l t t q) / a t q$ \\
\hline Profitability & EBITDA / Total Assets, i.e. oibdpq/atq \\
\hline Tangibility & PP\&E / Total Assets, i.e. ppentq/atq \\
\hline CashFlowRisk & $\begin{array}{l}\text { Variance of EBITDA calculated using all available observations in Com- } \\
\text { pustat, divided by Total Assets. }\end{array}$ \\
\hline Z-Score & $\begin{array}{l}\text { The Altman's Z-Score }=1.2 *((\text { actq }- \text { lctq }) / \text { atq })+1.4 *(\text { req } / \text { atq })+3.3 * \\
(\text { piq } / \text { atq })+0.6 *((\text { prccq } * \text { cshoq }) / \text { ltq })+0.999 *(\text { saleq } / \text { atq })\end{array}$ \\
\hline \multicolumn{2}{|c|}{ Loan characteristics } \\
\hline lnMaturity & The natural logarithm of the deal maturity measured in months \\
\hline $\ln A m o u n t$ & The natural logarithm of the deal amount measured in million U.S. dollar \\
\hline Syndication & Dummy $=1$ for syndicated loans \\
\hline Term Loan & Dummy $=1$ if the deal include a term loan \\
\hline Loan Purpose & $\begin{array}{l}\text { Dummies for the four loan purposes: acquisition purpose ("general } \\
\text { or specific acquisition program" or "LBO loans"), recapitalization pur- } \\
\text { pose("debt repayment/consolidation", "recapitalization" or "debtor-in- } \\
\text { possession loan"), general purpose ("working capital" or "general cor- } \\
\text { porate purpose") and others. }\end{array}$ \\
\hline \multicolumn{2}{|c|}{ Market and industry characteristics } \\
\hline HHI & The TNIC HHI developed in Hoberg and Phillips (2010a). \\
\hline Industry & Dummies using the SIC two-digit industry classification \\
\hline Year & Dummies for years 1998-2008 \\
\hline
\end{tabular}


Table 2: Summary Statistics

The table presents summary statistics for the variables described in Table 1. The data are obtained by merging the DealScan database with the CRSP-Compustat databases. We drop observations without borrower ID, total assets or fluidity information, and exclude financial firms and utilities. Panel A is for deals in the full sample. Panel B is for deals of small firms. Panel C and D are for PSD and non-PSD of small firms. Small firms are defined as those that have below-median total assets in Compustat in the year.

\begin{tabular}{|c|c|c|c|c|c|c|}
\hline Variable & Mean & p25 & p50 & p75 & SD & $\mathbf{N}$ \\
\hline \multicolumn{7}{|c|}{ Panel A: Full Sample } \\
\hline Fluidity & 6.71 & 4.27 & 6.08 & 8.59 & 3.29 & 16411 \\
\hline SingleSeg & 0.51 & 0.00 & 1.00 & 1.00 & 0.50 & 16411 \\
\hline PSD & 0.44 & 0.00 & 0.00 & 1.00 & 0.50 & 16411 \\
\hline DealAmount & 423.36 & 48.00 & 150.00 & 400.00 & 1023.21 & 16100 \\
\hline Maturity & 48.14 & 24.00 & 48.00 & 60.00 & 30.29 & 15219 \\
\hline Syndication & 0.85 & 1.00 & 1.00 & 1.00 & 0.36 & 16411 \\
\hline TermLoan & 0.31 & 0.00 & 0.00 & 1.00 & 0.46 & 16411 \\
\hline Assets & 5695.37 & 199.16 & 751.40 & 2909.86 & 24998.64 & 16411 \\
\hline Market-to-Book & 1.79 & 1.08 & 1.40 & 1.97 & 1.62 & 14560 \\
\hline Profitability & 0.03 & 0.02 & 0.03 & 0.05 & 0.05 & 15133 \\
\hline Leverage & 0.32 & 0.16 & 0.29 & 0.44 & 0.23 & 15676 \\
\hline Tangibility & 0.32 & 0.12 & 0.25 & 0.46 & 0.24 & 16289 \\
\hline CashFlowRisk & 0.02 & 0.01 & 0.01 & 0.02 & 0.03 & 15510 \\
\hline ZScore & 2.52 & 0.86 & 1.66 & 2.91 & 5.17 & 14860 \\
\hline HHI & 0.20 & 0.06 & 0.12 & 0.26 & 0.22 & 16402 \\
\hline \multicolumn{7}{|c|}{ Panel B: Small Firms } \\
\hline Fluidity & 6.64 & 4.38 & 6.17 & 8.45 & 3.05 & 3746 \\
\hline SingleSeg & 0.66 & 0.00 & 1.00 & 1.00 & 0.47 & 3746 \\
\hline PSD & 0.34 & 0.00 & 0.00 & 1.00 & 0.47 & 3746 \\
\hline DealAmount & 35.97 & 7.50 & 20.00 & 45.00 & 58.29 & 3700 \\
\hline Maturity & 39.28 & 23.00 & 36.00 & 60.00 & 25.67 & 3505 \\
\hline Syndication & 0.65 & 0.00 & 1.00 & 1.00 & 0.48 & 3746 \\
\hline TermLoan & 0.39 & 0.00 & 0.00 & 1.00 & 0.49 & 3746 \\
\hline Assets & 92.88 & 36.08 & 71.94 & 127.11 & 75.68 & 3746 \\
\hline Market-to-Book & 2.00 & 1.04 & 1.45 & 2.25 & 2.26 & 3627 \\
\hline Profitability & 0.01 & -0.00 & 0.03 & 0.05 & 0.08 & 3415 \\
\hline Leverage & 0.24 & 0.06 & 0.19 & 0.36 & 0.25 & 3654 \\
\hline Tangibility & 0.26 & 0.09 & 0.18 & 0.36 & 0.23 & 3733 \\
\hline CashFlowRisk & 0.03 & 0.01 & 0.02 & 0.03 & 0.05 & 3476 \\
\hline ZScore & 3.05 & 0.74 & 1.82 & 3.75 & 7.25 & 3583 \\
\hline HHI & 0.27 & 0.08 & 0.16 & 0.39 & 0.26 & 3742 \\
\hline
\end{tabular}


Table 3: Difference in Firm and Loan Characteristics: PSD and non-PSD

The table presents average firm and loan characteristics for PSD and non-PSD, and their differences, based on firm asset size. PSD is defined as a loan with at least one facility having the performancesensitive feature. Panel A and B include observations for small firms and large firms respectively. Small firms are defined as those that have below-median total assets in the Compustat dataset in the year. Variables are described in Table 1. Significance at the 10\%, 5\%, and $1 \%$ level is indicated by ${ }^{*},{ }^{* *}$, and ${ }^{* * *}$, respectively.

\begin{tabular}{|c|c|c|c|c|c|}
\hline \multirow[t]{2}{*}{ Variable } & \multicolumn{2}{|c|}{ PSD } & \multicolumn{2}{|c|}{ non-PSD } & \multirow[t]{2}{*}{ Difference } \\
\hline & $\mathbf{N}$ & Mean & $\mathbf{N}$ & Mean & \\
\hline \multicolumn{6}{|c|}{ Panel A: Small Firms } \\
\hline Fluidity & 1,261 & 6.29 & 2,485 & 6.82 & $-0.53^{* * *}$ \\
\hline SingleSeg & 1,261 & 0.59 & 2,485 & 0.69 & $-0.10 * * *$ \\
\hline DealAmount & 1,258 & 55.0 & 2,442 & 26.2 & $29.8^{* * *}$ \\
\hline Maturity & 1,248 & 46.2 & 2,257 & 35.4 & $10.8^{* * *}$ \\
\hline Syndication & 1,261 & 0.84 & 2,485 & 0.55 & $0.29 * * *$ \\
\hline TermLoan & 1,261 & 0.42 & 2,485 & 0.38 & $0.04^{* *}$ \\
\hline Assets & 1,261 & 125 & 2,485 & 77 & $48^{* * *}$ \\
\hline Market-to-Book & 1,212 & 1.77 & 2,415 & 2.12 & $-0.35^{* * *}$ \\
\hline Profitability & 1,171 & 0.03 & 2,244 & 0.00 & $0.03^{* * *}$ \\
\hline Leverage & 1,241 & 0.25 & 2,413 & 0.23 & 0.02 \\
\hline Tangibility & 1,261 & 0.28 & 2,472 & 0.25 & $0.03^{* * *}$ \\
\hline CashFlowRisk & 1,178 & 0.02 & 2,298 & 0.03 & $-0.01 * * *$ \\
\hline ZScore & 1,210 & 2.87 & 2,373 & 3.14 & -0.27 \\
\hline HHI & 1,259 & 0.27 & 2,483 & 0.27 & -0.00 \\
\hline \multicolumn{6}{|c|}{ Panel B: Large Firms } \\
\hline Fluidity & 6,032 & 6.59 & 6,633 & 6.85 & $-0.26^{* * *}$ \\
\hline SingleSeg & 6,032 & 0.47 & 6,633 & 0.47 & -0.00 \\
\hline DealAmount & 5,985 & 594 & 6,415 & 488 & $106^{* * *}$ \\
\hline Maturity & 6,006 & 51.1 & 5,708 & 50.4 & 0.07 \\
\hline Syndication & 6,032 & 0.98 & 6,633 & 0.83 & $0.15^{* * *}$ \\
\hline TermLoan & 6,032 & 0.31 & 6,633 & 0.27 & $0.04^{* * *}$ \\
\hline Assets & 6,032 & 4592 & 6,633 & 9862 & $-4270^{* * *}$ \\
\hline Market-to-Book & 5,256 & 1.68 & 5,677 & 1.76 & $-0.08 * * *$ \\
\hline Profitability & 5,628 & 0.04 & 6,090 & 0.03 & $0.01^{* * *}$ \\
\hline Leverage & 5,783 & 0.33 & 6,239 & 0.35 & $-0.02 * * *$ \\
\hline Tangibility & 5,989 & 0.33 & 6,567 & 0.34 & $-0.01^{* *}$ \\
\hline CashFlowRisk & 5,726 & 0.01 & 6,308 & 0.01 & -0.00 \\
\hline ZScore & 5,486 & 2.28 & 5,791 & 2.43 & $-0.15^{* *}$ \\
\hline HHI & 6,028 & 0.19 & 6,632 & 0.18 & $0.01^{* * *}$ \\
\hline
\end{tabular}


Table 4: Difference in Firm and Loan Characteristics: High Fluidity and Low Fluidity

The table presents average firm and loan characteristics for high-fluidity and low-fluidity observations, and their differences. For small and large firms respectively, we split the sample into loans with above-median (high) fluidity in the year and below-median (low) fluidity in the year. Panel A and B include observations for small firms and large firms respectively. Small firms are defined as those that have below-median total assets in the Compustat dataset in the year. Variables are described in Table 1. Significance at the $10 \%, 5 \%$, and $1 \%$ level is indicated by *, **, and ***, respectively.

\begin{tabular}{|c|c|c|c|c|c|}
\hline \multirow[t]{2}{*}{ Variable } & \multicolumn{2}{|c|}{ High Fluidity } & \multicolumn{2}{|c|}{ Low Fluidity } & \multirow[t]{2}{*}{ Difference } \\
\hline & $\mathbf{N}$ & Mean & $\mathbf{N}$ & Mean & \\
\hline \multicolumn{6}{|c|}{ Panel A: Small Firms } \\
\hline PSD & 1,868 & 0.31 & 1,874 & 0.36 & $-0.05^{* * *}$ \\
\hline SingleSeg & 1,870 & 0.67 & 1,876 & 0.64 & $0.03^{* *}$ \\
\hline DealAmount & 1,857 & 37.0 & 1,843 & 34.9 & 2.1 \\
\hline Maturity & 1,759 & 37.4 & 1,746 & 41.2 & $-3.8^{* * *}$ \\
\hline Syndication & 1,870 & 0.63 & 1,876 & 0.67 & $-0.04^{* * *}$ \\
\hline TermLoan & 1,870 & 0.38 & 1,876 & 0.40 & $-0.02^{* *}$ \\
\hline Assets & 1,870 & 94 & 1,876 & 92 & 2 \\
\hline Market-to-Book & 1,822 & 2.42 & 1,805 & 1.58 & $0.84^{* * *}$ \\
\hline Profitability & 1,714 & 0.00 & 1,701 & 0.03 & $-0.02^{* * *}$ \\
\hline Leverage & 1,814 & 0.22 & 1,840 & 0.26 & $-0.04^{* * *}$ \\
\hline Tangibility & 1,863 & 0.27 & 1,870 & 0.25 & $0.02^{* *}$ \\
\hline CashFlowRisk & 1,715 & 0.03 & 1,761 & 0.02 & $0.01^{* * *}$ \\
\hline ZScore & 1,770 & 3.51 & 1,813 & 2.60 & $0.91^{* * *}$ \\
\hline HHI & 1,868 & 0.19 & 1,874 & 0.35 & $-0.16^{* * *}$ \\
\hline \multicolumn{6}{|c|}{ Panel B: Large Firms } \\
\hline PSD & 6,325 & 0.46 & 6,340 & 0.49 & $-0.03^{* * *}$ \\
\hline SingleSeg & 6,325 & 0.50 & 6,340 & 0.44 & $0.06^{* * *}$ \\
\hline DealAmount & 6,176 & 564 & 6,224 & 515 & $49^{* *}$ \\
\hline Maturity & 5,834 & 52.8 & 5,880 & 48.7 & $4.16^{* * *}$ \\
\hline Syndication & 6,325 & 0.89 & 6,340 & 0.92 & $-0.03^{* * *}$ \\
\hline TermLoan & 6,325 & 0.33 & 6,340 & 0.25 & $0.08^{* * *}$ \\
\hline Assets & 6,325 & 8926 & 6,340 & 5782 & $3143^{* * *}$ \\
\hline Market-to-Book & 5,683 & 1.81 & 5,250 & 1.63 & $0.18^{* * *}$ \\
\hline Profitability & 5,908 & 0.03 & 5,810 & 0.04 & $-0.01^{* * *}$ \\
\hline Leverage & 5,989 & 0.36 & 6,033 & 0.32 & $0.04^{* * *}$ \\
\hline Tangibility & 6,264 & 0.37 & 6,292 & 0.29 & $0.08^{* * *}$ \\
\hline CashFlowRisk & 6,002 & 0.01 & 6,032 & 0.01 & -0.00 \\
\hline ZScore & 5,653 & 2.46 & 5,624 & 2.25 & $0.22^{* * *}$ \\
\hline HHI & 6,324 & 0.14 & 6,336 & 0.22 & $-0.08^{* * *}$ \\
\hline
\end{tabular}


Table 5: Difference in Firm and Loan Characteristics: Single-segmented and Multiple-segmented The table presents average firm and loan characteristics for single-segmented and multiple-segmented firms, and their differences. A single-segmented firm has only one business segment. Panel A and B include observations for small firms and large firms respectively. Small firms are defined as those that have below-median total assets in the Compustat dataset in the year. Variables are described in Table 1 . Significance at the $10 \%, 5 \%$, and $1 \%$ level is indicated by $* * *$, and ${ }^{* * *}$, respectively.

\begin{tabular}{|c|c|c|c|c|c|}
\hline \multirow[t]{2}{*}{ Variable } & \multicolumn{2}{|c|}{ Single-segmented } & \multicolumn{2}{|c|}{ Multiple-segmented } & \multirow[t]{2}{*}{ Difference } \\
\hline & $\mathbf{N}$ & Mean & $\mathbf{N}$ & Mean & \\
\hline \multicolumn{6}{|c|}{ Panel A: Small Firms } \\
\hline PSD & 2,460 & 0.30 & 1,286 & 0.40 & $-0.10^{* * *}$ \\
\hline Fluidity & 2,460 & 6.75 & 1,286 & 6.44 & $0.31^{* * *}$ \\
\hline DealAmount & 2,422 & 32.9 & 1,278 & 41.9 & $-9.0^{* * *}$ \\
\hline Maturity & 2,293 & 38.2 & 1,212 & 41.2 & $-2.97 * * *$ \\
\hline Syndication & 2,460 & 0.61 & 1,286 & 0.72 & $-0.12^{* * *}$ \\
\hline TermLoan & 2,460 & 0.37 & 1,286 & 0.42 & $-0.04^{* *}$ \\
\hline Assets & 2,460 & 85 & 1,286 & 107 & $-22^{* * *}$ \\
\hline Market-to-Book & 2,387 & 2.12 & 1,240 & 1.77 & $0.35^{* * *}$ \\
\hline Profitability & 2,250 & 0.01 & 1,165 & 0.02 & $-0.01^{* * *}$ \\
\hline Leverage & 2,396 & 0.24 & 1,258 & 0.24 & -0.00 \\
\hline Tangibility & 2,454 & 0.27 & 1,279 & 0.23 & $0.04^{* * *}$ \\
\hline CashFlowRisk & 2,256 & 0.03 & 1,220 & 0.02 & $0.01^{* * *}$ \\
\hline ZScore & 2,359 & 3.29 & 1,224 & 2.59 & $0.70^{* * *}$ \\
\hline HHI & 2,458 & 0.25 & 1,284 & 0.31 & $-0.06^{* * *}$ \\
\hline \multicolumn{6}{|c|}{ Panel B: Large Firms } \\
\hline PSD & 5,980 & 0.47 & 6,685 & 0.48 & -0.01 \\
\hline Fluidity & 5,980 & 6.96 & 6,685 & 6.51 & $0.45^{* * *}$ \\
\hline DealAmount & 5,853 & 493 & 6,547 & 580 & $-87^{* * *}$ \\
\hline Maturity & 5,531 & 53.4 & 6,183 & 48.5 & $4.86^{* * *}$ \\
\hline Syndication & 5,980 & 0.88 & 6,685 & 0.93 & $-0.05^{* * *}$ \\
\hline TermLoan & 5,980 & 0.30 & 6,685 & 0.28 & $0.02 *$ \\
\hline Assets & 5,980 & 6464 & 6,685 & 8146 & $-1681^{* * *}$ \\
\hline Market-to-Book & 5,221 & 1.83 & 5,712 & 1.62 & $0.22^{* * *}$ \\
\hline Profitability & 5,598 & 0.03 & 6,120 & 0.03 & $0.00^{* * *}$ \\
\hline Leverage & 5,669 & 0.36 & 6,353 & 0.32 & $0.04^{* * *}$ \\
\hline Tangibility & 5,937 & 0.37 & 6,619 & 0.30 & $0.07^{* * *}$ \\
\hline CashFlowRisk & 5,653 & 0.01 & 6,381 & 0.01 & $0.00^{* * *}$ \\
\hline ZScore & 5,417 & 2.58 & 5,860 & 2.14 & $0.44^{* * *}$ \\
\hline HHI & 5,978 & 0.17 & 6,682 & 0.19 & $-0.02 * * *$ \\
\hline
\end{tabular}


Table 6: Predatory Threats and the Use of PSD

This table shows estimated marginal effects from cross-sectional Probit regressions where the dependent variable is the dummy variable for PSD. In model (1)-(5), the proxy for predatory threats is product fluidity, while it is the dummy for single segmented firms in model (6)-(10). The sample used is indicated by the column headers. Small (large) firms are defined as those having below-median (above-median) asset size in the Compustat database, split on a yearly basis. All regressions include year, industry (2-digit SIC code) and loan purpose fixed effects. Marginal effects for a given independent variable are calculated holding other variables constant at their average value. The pseudo $R^{2}$ is calculated as McFadden's (adjusted) $R^{2}$ from McFadden (1974). Standard errors are clustered at the firm level and corrected for heteroskedasticity. Significance at the $10 \%, 5 \%$, and $1 \%$ level is indicated by *, **, and ${ }^{* *}$, respectively. t-values are shown in parentheses.

\begin{tabular}{|c|c|c|c|c|c|c|c|c|c|c|}
\hline & $\begin{array}{c}(1) \\
\text { Small }\end{array}$ & $\begin{array}{l}(2) \\
\text { Small }\end{array}$ & $\begin{array}{c}(3) \\
\text { Large }\end{array}$ & $\begin{array}{c}(4) \\
\text { Small }\end{array}$ & $\begin{array}{c}(5) \\
\text { Large }\end{array}$ & $\begin{array}{c}(6) \\
\text { Small }\end{array}$ & $\begin{array}{c}(7) \\
\text { Small }\end{array}$ & $\begin{array}{c}(8) \\
\text { Large }\end{array}$ & $\begin{array}{c}(9) \\
\text { Small }\end{array}$ & $\begin{array}{l}(10) \\
\text { Large }\end{array}$ \\
\hline Fluidity & $\begin{array}{c}-0.017^{* * *} \\
(-4.85)\end{array}$ & $\begin{array}{c}-0.011^{* * *} \\
(-2.73)\end{array}$ & $\begin{array}{l}-0.005^{*} \\
(-1.95)\end{array}$ & $\begin{array}{c}-0.011^{* * *} \\
(-2.63)\end{array}$ & $\begin{array}{l}-0.003 \\
(-0.91)\end{array}$ & & & & & \\
\hline SingleSeg & & & & & & $\begin{array}{c}-0.078^{* * *} \\
(-4.12)\end{array}$ & $\begin{array}{c}-0.059^{* * *} \\
(-2.85)\end{array}$ & $\begin{array}{l}-0.006 \\
(-0.41)\end{array}$ & $\begin{array}{c}-0.059^{* * *} \\
(-2.64)\end{array}$ & $\begin{array}{l}-0.013 \\
(-0.80)\end{array}$ \\
\hline ZScore & & $\begin{array}{l}-0.003 \\
(-1.52)\end{array}$ & $\begin{array}{c}-0.005^{*} \\
(-1.71)\end{array}$ & $\begin{array}{l}-0.004 \\
(-1.57)\end{array}$ & $\begin{array}{l}-0.002 \\
(-0.53)\end{array}$ & & $\begin{array}{l}-0.003 \\
(-1.30)\end{array}$ & $\begin{array}{c}-0.006^{*} \\
(-1.80)\end{array}$ & $\begin{array}{l}-0.003 \\
(-1.33)\end{array}$ & $\begin{array}{l}-0.002 \\
(-0.56)\end{array}$ \\
\hline lnAssets & & $\begin{array}{c}0.158^{* * * *} \\
(11.51)\end{array}$ & $\begin{array}{c}-0.048^{* * *} \\
(-7.58)\end{array}$ & $\begin{array}{l}0.018 \\
(0.96)\end{array}$ & $\begin{array}{c}-0.133^{* * * *} \\
(-14.53)\end{array}$ & & $\begin{array}{c}0.150^{* * * *} \\
(11.10)\end{array}$ & $\begin{array}{c}-0.048^{* * * *} \\
(-7.74)\end{array}$ & $\begin{array}{l}0.008 \\
(0.44)\end{array}$ & $\begin{array}{c}-0.135 * * * \\
(-14.66)\end{array}$ \\
\hline Profitability & & $\begin{array}{c}1.270^{* * *} \\
(4.94)\end{array}$ & $\begin{array}{c}1.191^{* * *} \\
(4.25)\end{array}$ & $\begin{array}{c}0.882^{* * *} \\
(3.45)\end{array}$ & $\begin{array}{c}0.732 * * * \\
(2.76)\end{array}$ & & $\begin{array}{c}1.379^{* * * *} \\
(5.46)\end{array}$ & $\begin{array}{c}1.248^{* * * *} \\
(4.44)\end{array}$ & $\begin{array}{c}0.987 * * * \\
(3.91)\end{array}$ & $\begin{array}{c}0.758^{* * * *} \\
(2.87)\end{array}$ \\
\hline Q & & $\begin{array}{l}-0.010 \\
(-1.23)\end{array}$ & $\begin{array}{l}-0.013 \\
(-1.39)\end{array}$ & $\begin{array}{l}-0.007 \\
(-0.77)\end{array}$ & $\begin{array}{l}-0.015 \\
(-1.41)\end{array}$ & & $\begin{array}{c}-0.015^{*} \\
(-1.85)\end{array}$ & $\begin{array}{l}-0.014 \\
(-1.44)\end{array}$ & $\begin{array}{l}-0.013 \\
(-1.37)\end{array}$ & $\begin{array}{l}-0.015 \\
(-1.40)\end{array}$ \\
\hline Leverage & & $\begin{array}{l}-0.010 \\
(-0.19)\end{array}$ & $\begin{array}{c}-0.179^{* * *} \\
(-4.91)\end{array}$ & $\begin{array}{c}-0.205^{* * * *} \\
(-3.70)\end{array}$ & $\begin{array}{c}-0.268^{* * * *} \\
(-6.15)\end{array}$ & & $\begin{array}{l}0.004 \\
(0.08)\end{array}$ & $\begin{array}{c}-0.183^{* * *} \\
(-4.99)\end{array}$ & $\begin{array}{c}-0.189^{* * * *} \\
(-3.43)\end{array}$ & $\begin{array}{c}-0.269^{* * * *} \\
(-6.16)\end{array}$ \\
\hline CashFlowRisk & & $\begin{array}{c}-0.648^{*} \\
(-1.95)\end{array}$ & $\begin{array}{l}-0.861 \\
(-1.39)\end{array}$ & $\begin{array}{c}-0.736^{* *} \\
(-2.09)\end{array}$ & $\begin{array}{l}-0.811 \\
(-1.29)\end{array}$ & & $\begin{array}{c}-0.623^{*} \\
(-1.86)\end{array}$ & $\begin{array}{l}-0.871 \\
(-1.40)\end{array}$ & $\begin{array}{c}-0.712^{* *} \\
(-2.04)\end{array}$ & $\begin{array}{l}-0.800 \\
(-1.26)\end{array}$ \\
\hline Tangibility & & $\begin{array}{l}0.025 \\
(0.42)\end{array}$ & $\begin{array}{l}0.011 \\
(0.25)\end{array}$ & $\begin{array}{c}0.129^{* *} \\
(2.00)\end{array}$ & $\begin{array}{l}0.069 \\
(1.48)\end{array}$ & & $\begin{array}{l}0.031 \\
(0.50)\end{array}$ & $\begin{array}{l}0.009 \\
(0.20)\end{array}$ & $\begin{array}{c}0.131^{* *} \\
(2.04)\end{array}$ & $\begin{array}{l}0.071 \\
(1.51)\end{array}$ \\
\hline Syndication & & & & $\begin{array}{c}0.118^{* * *} \\
(4.53)\end{array}$ & $\begin{array}{c}0.441^{* * *} \\
(22.32)\end{array}$ & & & & $\begin{array}{c}0.124^{* * *} \\
(4.79)\end{array}$ & $\begin{array}{c}0.441^{* * *} \\
(22.33)\end{array}$ \\
\hline lnMaturity & & & & $\begin{array}{c}0.112^{* * *} \\
(5.86)\end{array}$ & $\begin{array}{c}0.074^{* * *} \\
(6.56)\end{array}$ & & & & $\begin{array}{c}0.112^{* * *} \\
(5.84)\end{array}$ & $\begin{array}{c}0.074^{* * *} \\
(6.55)\end{array}$ \\
\hline $\ln A m o u n t$ & & & & $\begin{array}{c}0.147^{* * *} \\
(8.95)\end{array}$ & $\begin{array}{c}0.151^{* * *} \\
(16.15)\end{array}$ & & & & $\begin{array}{c}0.148^{* * *} \\
(8.99)\end{array}$ & $\begin{array}{c}0.151^{* * *} \\
(16.21)\end{array}$ \\
\hline TermLoan & & & & $\begin{array}{c}-0.059^{* *} \\
(-2.52)\end{array}$ & $\begin{array}{c}-0.091^{* * *} \\
(-5.48)\end{array}$ & & & & $\begin{array}{c}-0.062^{* * *} \\
(-2.66)\end{array}$ & $\begin{array}{c}-0.091^{* * * *} \\
(-5.50)\end{array}$ \\
\hline Loan Purpose & No & No & No & Yes & Yes & No & No & No & Yes & Yes \\
\hline Industry & Yes & Yes & Yes & Yes & Yes & Yes & Yes & Yes & Yes & Yes \\
\hline Year & Yes & Yes & Yes & Yes & Yes & Yes & Yes & Yes & Yes & Yes \\
\hline $\begin{array}{l}N \\
\text { pseudo } R^{2}\end{array}$ & $\begin{array}{c}3727 \\
0.0838\end{array}$ & $\begin{array}{c}3025 \\
0.1486\end{array}$ & $\begin{array}{c}8895 \\
0.0498\end{array}$ & $\begin{array}{c}2787 \\
0.2383\end{array}$ & $\begin{array}{c}8104 \\
0.1637\end{array}$ & $\begin{array}{c}3727 \\
0.0818\end{array}$ & $\begin{array}{c}3025 \\
0.1487\end{array}$ & $\begin{array}{c}8895 \\
0.0494\end{array}$ & $\begin{array}{c}2787 \\
0.2383\end{array}$ & $\begin{array}{c}8104 \\
0.1637\end{array}$ \\
\hline
\end{tabular}




\section{Table 7: Predatory Threats and the Use of PSD: the Role of Growth Opportunities}

This table shows estimated marginal effects from cross sectional Probit regressions, where the dependent variables is the dummy variable for PSD. The sample used includes only small firms, which are defined as those having below-median asset size in the Compustat database in the observed year. All regressions include year, industry (2-digit SIC code) and loan purpose fixed effects. Marginal effects for a given independent variable are calculated holding other variables constant at their average value. The pseudo $R^{2}$ is calculated as McFadden's (adjusted) $R^{2}$ from McFadden (1974). Standard errors are clustered at the firm level and corrected for heteroskedasticity. Significance at the $10 \%, 5 \%$, and $1 \%$ level is indicated by $*^{* *}$, and ${ }^{* * *}$, respectively. t-values are shown in parentheses.

\begin{tabular}{|c|c|c|c|c|c|c|}
\hline & $\begin{array}{c}(1) \\
\mathrm{RD}=0\end{array}$ & $\begin{array}{c}(2) \\
\mathrm{RD}>0\end{array}$ & $\begin{array}{c}(3) \\
\mathrm{RD}=0\end{array}$ & $\begin{array}{c}(4) \\
\mathrm{RD}>0\end{array}$ & $\begin{array}{c}(5) \\
\mathrm{RD}=0\end{array}$ & $\begin{array}{c}(6) \\
\mathrm{RD}>0\end{array}$ \\
\hline Fluidity & $\begin{array}{l}-0.001 \\
(-0.24)\end{array}$ & $\begin{array}{c}-0.025^{* * *} \\
(-4.96)\end{array}$ & $\begin{array}{l}-0.004 \\
(-0.58)\end{array}$ & $\begin{array}{c}-0.015^{* * *} \\
(-2.70)\end{array}$ & $\begin{array}{l}-0.009 \\
(-1.22)\end{array}$ & $\begin{array}{c}-0.012^{*} \\
(-1.92)\end{array}$ \\
\hline ZScore & & & $\begin{array}{c}-0.010^{*} \\
(-1.82)\end{array}$ & $\begin{array}{l}0.000 \\
(0.02)\end{array}$ & $\begin{array}{l}-0.012 \\
(-1.48)\end{array}$ & $\begin{array}{l}-0.000 \\
(-0.03)\end{array}$ \\
\hline lnAssets & & & $\begin{array}{c}0.179^{* * *} \\
(7.76)\end{array}$ & $\begin{array}{c}0.162^{* * * *} \\
(8.40)\end{array}$ & $\begin{array}{l}-0.003 \\
(-0.10)\end{array}$ & $\begin{array}{c}0.054^{* *} \\
(2.00)\end{array}$ \\
\hline Profitability & & & $\begin{array}{c}1.149^{* *} \\
(2.51)\end{array}$ & $\begin{array}{c}1.607^{* * *} \\
(5.34)\end{array}$ & $\begin{array}{c}0.973^{* *} \\
(2.08)\end{array}$ & $\begin{array}{c}1.114^{* * *} \\
(3.73)\end{array}$ \\
\hline $\mathrm{Q}$ & & & $\begin{array}{l}-0.002 \\
(-0.10)\end{array}$ & $\begin{array}{l}-0.015 \\
(-1.32)\end{array}$ & $\begin{array}{l}0.004 \\
(0.15)\end{array}$ & $\begin{array}{l}-0.013 \\
(-1.10)\end{array}$ \\
\hline Leverage & & & $\begin{array}{l}0.006 \\
(0.06)\end{array}$ & $\begin{array}{l}0.166^{*} \\
(1.79)\end{array}$ & $\begin{array}{c}-0.228^{* *} \\
(-2.06)\end{array}$ & $\begin{array}{l}0.046 \\
(0.44)\end{array}$ \\
\hline CashFlowRisk & & & $\begin{array}{l}-0.208 \\
(-0.47)\end{array}$ & $\begin{array}{l}0.019 \\
(0.03)\end{array}$ & $\begin{array}{l}-0.475 \\
(-0.92)\end{array}$ & $\begin{array}{l}-0.085 \\
(-0.13)\end{array}$ \\
\hline Tangibility & & & $\begin{array}{l}-0.020 \\
(-0.20)\end{array}$ & $\begin{array}{l}0.026 \\
(0.27)\end{array}$ & $\begin{array}{c}0.177^{*} \\
(1.70)\end{array}$ & $\begin{array}{l}0.109 \\
(1.09)\end{array}$ \\
\hline Syndication & & & & & $\begin{array}{c}0.131^{* * *} \\
(2.94)\end{array}$ & $\begin{array}{c}0.070^{* *} \\
(1.99)\end{array}$ \\
\hline lnMaturity & & & & & $\begin{array}{c}0.123^{* * *} \\
(3.41)\end{array}$ & $\begin{array}{c}0.123^{* * *} \\
(4.62)\end{array}$ \\
\hline $\ln$ Amount & & & & & $\begin{array}{c}0.189^{* * *} \\
(7.05)\end{array}$ & $\begin{array}{c}0.121^{* * *} \\
(5.34)\end{array}$ \\
\hline TermLoan & & & & & $\begin{array}{l}-0.033 \\
(-0.92)\end{array}$ & $\begin{array}{c}-0.116^{* * *} \\
(-3.33)\end{array}$ \\
\hline Loan Purpose & No & No & No & No & Yes & Yes \\
\hline Industry & Yes & Yes & Yes & Yes & Yes & Yes \\
\hline Year & Yes & Yes & Yes & Yes & Yes & Yes \\
\hline $\begin{array}{l}N \\
\text { pseudo } R^{2}\end{array}$ & $\begin{array}{c}1719 \\
0.0845\end{array}$ & $\begin{array}{c}1349 \\
0.0893\end{array}$ & $\begin{array}{c}1446 \\
0.1331\end{array}$ & $\begin{array}{c}1132 \\
0.1943\end{array}$ & $\begin{array}{c}1330 \\
0.2323\end{array}$ & $\begin{array}{c}1051 \\
0.2726\end{array}$ \\
\hline
\end{tabular}


Table 8: Predatory Threats and the Use of PSD: Controlling for HHI

This table shows estimated marginal effects from cross-sectional Probit regressions where the dependent variable is a dummy variable for PSD. The sample used includes only small firms, which are defined as those having below-median asset size in the Compustat database in the observed year. All regressions include year, industry (2-digit SIC code) and loan purpose fixed effects. Marginal effects for a given independent variable are calculated holding other variables constant at their average value. The pseudo $R^{2}$ is calculated as McFadden's (adjusted) $R^{2}$ from McFadden (1974). Standard errors are clustered at the firm level and corrected for heteroskedasticity. Significance at the 10\%, $5 \%$, and $1 \%$ level is indicated by $*{ }^{* *}$, and $* * *$, respectively. t-values are shown in parentheses.

\begin{tabular}{|c|c|c|c|c|c|c|}
\hline & (1) & (2) & (3) & (4) & (5) & (6) \\
\hline Fluidity & $\begin{array}{c}-0.020^{* * *} \\
(-5.40)\end{array}$ & $\begin{array}{c}-0.013^{* * *} \\
(-2.95)\end{array}$ & $\begin{array}{c}-0.013^{* * *} \\
(-2.89)\end{array}$ & & & \\
\hline SingleSeg & & & & $\begin{array}{c}-0.080^{* * *} \\
(-4.23)\end{array}$ & $\begin{array}{c}-0.060^{* * *} \\
(-2.91)\end{array}$ & $\begin{array}{c}-0.060^{* * *} \\
(-2.70)\end{array}$ \\
\hline HHI & $\begin{array}{c}-0.105^{* * *} \\
(-2.66)\end{array}$ & $\begin{array}{l}-0.044 \\
(-1.05)\end{array}$ & $\begin{array}{l}-0.057 \\
(-1.25)\end{array}$ & $\begin{array}{l}-0.047 \\
(-1.30)\end{array}$ & $\begin{array}{l}-0.014 \\
(-0.35)\end{array}$ & $\begin{array}{l}-0.024 \\
(-0.57)\end{array}$ \\
\hline ZScore & & $\begin{array}{l}-0.003 \\
(-1.51)\end{array}$ & $\begin{array}{l}-0.004 \\
(-1.57)\end{array}$ & & $\begin{array}{l}-0.003 \\
(-1.27)\end{array}$ & $\begin{array}{l}-0.003 \\
(-1.31)\end{array}$ \\
\hline lnAssets & & $\begin{array}{c}0.157^{* * *} \\
(11.42)\end{array}$ & $\begin{array}{l}0.018 \\
(0.92)\end{array}$ & & $\begin{array}{c}0.150^{* * *} \\
(10.95)\end{array}$ & $\begin{array}{l}0.008 \\
(0.41)\end{array}$ \\
\hline Profitability & & $\begin{array}{c}1.269^{* * *} \\
(4.94)\end{array}$ & $\begin{array}{c}0.888^{* * *} \\
(3.47)\end{array}$ & & $\begin{array}{c}1.380^{* * *} \\
(5.42)\end{array}$ & $\begin{array}{c}0.995^{* * *} \\
(3.90)\end{array}$ \\
\hline Q & & $\begin{array}{l}-0.010 \\
(-1.24)\end{array}$ & $\begin{array}{l}-0.007 \\
(-0.78)\end{array}$ & & $\begin{array}{c}-0.015^{*} \\
(-1.88)\end{array}$ & $\begin{array}{l}-0.013 \\
(-1.42)\end{array}$ \\
\hline Leverage & & $\begin{array}{l}-0.003 \\
(-0.06)\end{array}$ & $\begin{array}{c}-0.199^{* * *} \\
(-3.57)\end{array}$ & & $\begin{array}{l}0.008 \\
(0.16)\end{array}$ & $\begin{array}{c}-0.184^{* * *} \\
(-3.32)\end{array}$ \\
\hline CashFlowRisk & & $\begin{array}{c}-0.642^{*} \\
(-1.94)\end{array}$ & $\begin{array}{c}-0.727^{* *} \\
(-2.08)\end{array}$ & & $\begin{array}{c}-0.617^{*} \\
(-1.85)\end{array}$ & $\begin{array}{c}-0.705^{* *} \\
(-2.02)\end{array}$ \\
\hline Tangibility & & $\begin{array}{l}0.022 \\
(0.36)\end{array}$ & $\begin{array}{c}0.125^{*} \\
(1.92)\end{array}$ & & $\begin{array}{l}0.029 \\
(0.47)\end{array}$ & $\begin{array}{c}0.128^{* *} \\
(1.98)\end{array}$ \\
\hline Syndication & & & $\begin{array}{c}0.116^{* * *} \\
(4.46)\end{array}$ & & & $\begin{array}{c}0.123^{* * *} \\
(4.76)\end{array}$ \\
\hline lnMaturity & & & $\begin{array}{c}0.112^{* * *} \\
(5.87)\end{array}$ & & & $\begin{array}{c}0.112^{* * *} \\
(5.85)\end{array}$ \\
\hline lnAmount & & & $\begin{array}{c}0.147^{* * *} \\
(8.92)\end{array}$ & & & $\begin{array}{c}0.148^{* * *} \\
(8.97)\end{array}$ \\
\hline TermLoan & & & $\begin{array}{c}-0.057^{* *} \\
(-2.47)\end{array}$ & & & $\begin{array}{c}-0.062^{* * *} \\
(-2.64)\end{array}$ \\
\hline Loan Purpose & No & No & Yes & No & No & Yes \\
\hline Industry & Yes & Yes & Yes & Yes & Yes & Yes \\
\hline Year & Yes & Yes & Yes & Yes & Yes & Yes \\
\hline $\begin{array}{l}N \\
\text { pseudo } R^{2}\end{array}$ & $\begin{array}{c}3723 \\
0.0856\end{array}$ & $\begin{array}{c}3021 \\
0.1487\end{array}$ & $\begin{array}{c}2783 \\
0.2385\end{array}$ & $\begin{array}{c}3723 \\
0.0820\end{array}$ & $\begin{array}{c}3021 \\
0.1485\end{array}$ & $\begin{array}{c}2783 \\
0.2380\end{array}$ \\
\hline
\end{tabular}




\section{Table 9: Predatory Threats and the Use of PSD: 3-digit SIC Codes}

This table shows estimated marginal effects from cross-sectional Probit regressions where the dependent variable is a dummy variable for PSD. The sample used includes only small firms, which are defined as those having below-median asset size in the Compustat database in the observed year. All regressions include year, industry (3-digit SIC code) and loan purpose fixed effects. Marginal effects for a given independent variable are calculated holding other variables constant at their average value. The pseudo $R^{2}$ is calculated as McFadden's (adjusted) $R^{2}$ from McFadden (1974). Standard errors are clustered at the firm level and corrected for heteroskedasticity. Significance at the 10\%, $5 \%$, and $1 \%$ level is indicated by $*{ }^{* *}$, and ${ }^{* * *}$, respectively. t-values are shown in parentheses.

\begin{tabular}{|c|c|c|c|c|c|c|}
\hline & (1) & (2) & (3) & (4) & (5) & (6) \\
\hline Fluidity & $\begin{array}{c}-0.017^{* * *} \\
(-4.46)\end{array}$ & $\begin{array}{c}-0.012^{* * *} \\
(-2.81)\end{array}$ & $\begin{array}{c}-0.013^{* * *} \\
(-2.83)\end{array}$ & & & \\
\hline SingleSeg & & & & $\begin{array}{c}-0.077^{* * *} \\
(-3.86)\end{array}$ & $\begin{array}{c}-0.061^{* * *} \\
(-2.78)\end{array}$ & $\begin{array}{c}-0.056^{* *} \\
(-2.34)\end{array}$ \\
\hline ZScore & & $\begin{array}{c}-0.004^{*} \\
(-1.72)\end{array}$ & $\begin{array}{l}-0.004 \\
(-1.41)\end{array}$ & & $\begin{array}{l}-0.003 \\
(-1.49)\end{array}$ & $\begin{array}{l}-0.003 \\
(-1.15)\end{array}$ \\
\hline lnAssets & & $\begin{array}{c}0.159^{* * *} \\
(11.03)\end{array}$ & $\begin{array}{l}0.015 \\
(0.72)\end{array}$ & & $\begin{array}{c}0.149^{* * *} \\
(10.58)\end{array}$ & $\begin{array}{l}0.003 \\
(0.14)\end{array}$ \\
\hline Profitability & & $\begin{array}{c}1.147^{* * *} \\
(4.63)\end{array}$ & $\begin{array}{c}0.786^{* * *} \\
(3.34)\end{array}$ & & $\begin{array}{c}1.267^{* * *} \\
(5.14)\end{array}$ & $\begin{array}{c}0.920^{* * *} \\
(3.90)\end{array}$ \\
\hline $\mathrm{Q}$ & & $\begin{array}{l}-0.010 \\
(-1.14)\end{array}$ & $\begin{array}{l}-0.011 \\
(-1.09)\end{array}$ & & $\begin{array}{c}-0.014^{*} \\
(-1.70)\end{array}$ & $\begin{array}{c}-0.017^{*} \\
(-1.71)\end{array}$ \\
\hline Leverage & & $\begin{array}{l}-0.027 \\
(-0.50)\end{array}$ & $\begin{array}{c}-0.217^{* * *} \\
(-3.71)\end{array}$ & & $\begin{array}{l}-0.012 \\
(-0.22)\end{array}$ & $\begin{array}{c}-0.199^{* * *} \\
(-3.39)\end{array}$ \\
\hline CashFlowRisk & & $\begin{array}{c}-0.736^{* *} \\
(-2.11)\end{array}$ & $\begin{array}{c}-0.725^{* *} \\
(-2.00)\end{array}$ & & $\begin{array}{c}-0.721^{* *} \\
(-2.03)\end{array}$ & $\begin{array}{c}-0.717^{* *} \\
(-1.97)\end{array}$ \\
\hline Tangibility & & $\begin{array}{l}0.011 \\
(0.16)\end{array}$ & $\begin{array}{l}0.123^{*} \\
(1.71)\end{array}$ & & $\begin{array}{l}0.019 \\
(0.28)\end{array}$ & $\begin{array}{l}0.127^{*} \\
(1.75)\end{array}$ \\
\hline Syndication & & & $\begin{array}{c}0.131^{* * *} \\
(4.93)\end{array}$ & & & $\begin{array}{c}0.136^{* * *} \\
(5.07)\end{array}$ \\
\hline lnMaturity & & & $\begin{array}{c}0.116^{* * *} \\
(5.58)\end{array}$ & & & $\begin{array}{c}0.116^{* * *} \\
(5.56)\end{array}$ \\
\hline $\ln A m o u n t$ & & & $\begin{array}{c}0.153^{* * *} \\
(8.85)\end{array}$ & & & $\begin{array}{c}0.154^{* * *} \\
(8.88)\end{array}$ \\
\hline TermLoan & & & $\begin{array}{c}-0.062^{* *} \\
(-2.49)\end{array}$ & & & $\begin{array}{c}-0.064^{* * *} \\
(-2.60)\end{array}$ \\
\hline Loan Purpose & No & No & Yes & No & No & Yes \\
\hline Industry & Yes & Yes & Yes & Yes & Yes & Yes \\
\hline Year & Yes & Yes & Yes & Yes & Yes & Yes \\
\hline $\begin{array}{l}N \\
\text { pseudo } R^{2}\end{array}$ & $\begin{array}{c}3624 \\
0.1206\end{array}$ & $\begin{array}{c}2926 \\
0.1869\end{array}$ & $\begin{array}{c}2694 \\
0.2742\end{array}$ & $\begin{array}{c}3624 \\
0.1193\end{array}$ & $\begin{array}{c}2926 \\
0.1870\end{array}$ & $\begin{array}{c}2694 \\
0.2735\end{array}$ \\
\hline
\end{tabular}




\section{Table 10: Predatory Threats and the Use of PSD: OLS Regressions}

This table shows estimated coefficients from cross-sectional OLS regressions where the dependent variable is the dummy variable for PSD. The sample used includes only small firms, which are defined as those having below-median asset size in the Compustat database in the observed year. All regressions include year, industry (2-digit SIC code) and loan purpose fixed effects. Marginal effects for a given independent variable are calculated holding other variables constant at their average value. The pseudo $R^{2}$ is calculated as McFadden's (adjusted) $R^{2}$ from McFadden (1974). Standard errors are clustered at the firm level and corrected for heteroskedasticity. Significance at the $10 \%, 5 \%$, and $1 \%$ level is indicated by $*, * *$, and $* * *$, respectively. t-values are shown in parentheses.

\begin{tabular}{|c|c|c|c|c|c|c|}
\hline & (1) & (2) & (3) & (4) & (5) & (6) \\
\hline Fluidity & $\begin{array}{c}-0.014^{* * *} \\
(-4.70)\end{array}$ & $\begin{array}{c}-0.012^{* * *} \\
(-3.62)\end{array}$ & $\begin{array}{c}-0.010^{* * *} \\
(-3.12)\end{array}$ & & & \\
\hline SingleSeg & & & & $\begin{array}{c}-0.072^{* * *} \\
(-4.04)\end{array}$ & $\begin{array}{c}-0.063^{* * *} \\
(-3.22)\end{array}$ & $\begin{array}{c}-0.054^{* * *} \\
(-2.83)\end{array}$ \\
\hline ZScore & & $\begin{array}{c}-0.004^{* * *} \\
(-2.96)\end{array}$ & $\begin{array}{c}-0.003^{* * *} \\
(-2.64)\end{array}$ & & $\begin{array}{c}-0.004^{* * *} \\
(-2.76)\end{array}$ & $\begin{array}{c}-0.003^{* *} \\
(-2.51)\end{array}$ \\
\hline lnAssets & & $\begin{array}{c}0.135^{* * *} \\
(12.76)\end{array}$ & $\begin{array}{l}0.010 \\
(0.67)\end{array}$ & & $\begin{array}{c}0.127^{* * *} \\
(12.09)\end{array}$ & $\begin{array}{l}0.000 \\
(0.01)\end{array}$ \\
\hline Profitability & & $\begin{array}{c}0.483^{* * *} \\
(3.94)\end{array}$ & $\begin{array}{c}0.359^{* * *} \\
(2.76)\end{array}$ & & $\begin{array}{c}0.562^{* * *} \\
(4.64)\end{array}$ & $\begin{array}{c}0.425 * * * \\
(3.32)\end{array}$ \\
\hline Q & & $\begin{array}{l}0.007 \\
(1.56)\end{array}$ & $\begin{array}{c}0.008^{*} \\
(1.85)\end{array}$ & & $\begin{array}{l}0.005 \\
(0.97)\end{array}$ & $\begin{array}{l}0.007 \\
(1.34)\end{array}$ \\
\hline Leverage & & $\begin{array}{l}-0.025 \\
(-0.67)\end{array}$ & $\begin{array}{c}-0.152^{* * *} \\
(-3.85)\end{array}$ & & $\begin{array}{l}-0.012 \\
(-0.31)\end{array}$ & $\begin{array}{c}-0.142^{* * *} \\
(-3.61)\end{array}$ \\
\hline CashFlowRisk & & $\begin{array}{l}-0.181 \\
(-1.25)\end{array}$ & $\begin{array}{l}-0.202 \\
(-1.12)\end{array}$ & & $\begin{array}{l}-0.188 \\
(-1.31)\end{array}$ & $\begin{array}{l}-0.210 \\
(-1.19)\end{array}$ \\
\hline Tangibility & & $\begin{array}{l}0.037 \\
(0.65)\end{array}$ & $\begin{array}{c}0.129^{* *} \\
(2.29)\end{array}$ & & $\begin{array}{l}0.045 \\
(0.79)\end{array}$ & $\begin{array}{c}0.134^{* *} \\
(2.39)\end{array}$ \\
\hline Syndication & & & $\begin{array}{c}0.102^{* * *} \\
(4.73)\end{array}$ & & & $\begin{array}{c}0.107 * * * \\
(4.95)\end{array}$ \\
\hline lnMaturity & & & $\begin{array}{c}0.081^{* * *} \\
(6.06)\end{array}$ & & & $\begin{array}{c}0.081^{* * *} \\
(6.05)\end{array}$ \\
\hline lnAmount & & & $\begin{array}{c}0.123^{* * *} \\
(10.35)\end{array}$ & & & $\begin{array}{c}0.125^{* * *} \\
(10.47)\end{array}$ \\
\hline TermLoan & & & $\begin{array}{c}-0.042^{* *} \\
(-2.17)\end{array}$ & & & $\begin{array}{c}-0.045^{* *} \\
(-2.33)\end{array}$ \\
\hline Loan Purpose & No & No & Yes & No & No & Yes \\
\hline Industry & Yes & Yes & Yes & Yes & Yes & Yes \\
\hline Year & Yes & Yes & Yes & Yes & Yes & Yes \\
\hline$N$ & 3,746 & 3,051 & 2,810 & 3,746 & 3,051 & 2,810 \\
\hline adj. $R^{2}$ & 0.0925 & 0.1452 & 0.2416 & 0.0909 & 0.1445 & 0.2413 \\
\hline
\end{tabular}




\section{Table 11: Predatory Threats and the Use of PSD: Facility-level Results}

This table shows estimated marginal effects from cross-sectional Probit regressions where the dependent variable is a dummy variable for PSD. The sample used includes only small firms, which are defined as those having below-median asset size in the Compustat database in the observed year. All regressions include year, industry (2-digit SIC code) and loan purpose fixed effects. Marginal effects for a given independent variable are calculated holding other variables constant at their average value. The pseudo $R^{2}$ is calculated as McFadden's (adjusted) $R^{2}$ from McFadden (1974). Standard errors are clustered at the firm level and corrected for heteroskedasticity. Significance at the 10\%, $5 \%$, and $1 \%$ level is indicated by $*{ }^{* *}$, and $* * *$, respectively. t-values are shown in parentheses.

\begin{tabular}{|c|c|c|c|c|c|c|}
\hline & (1) & (2) & (3) & (4) & (5) & (6) \\
\hline Fluidity & $\begin{array}{c}-0.016^{* * *} \\
(-4.40)\end{array}$ & $\begin{array}{c}-0.010^{* *} \\
(-2.46)\end{array}$ & $\begin{array}{c}-0.011^{* *} \\
(-2.45)\end{array}$ & & & \\
\hline SingleSeg & & & & $\begin{array}{c}-0.068^{* * *} \\
(-3.36)\end{array}$ & $\begin{array}{c}-0.053^{* *} \\
(-2.41)\end{array}$ & $\begin{array}{c}-0.053^{* *} \\
(-2.30)\end{array}$ \\
\hline ZScore & & $\begin{array}{l}-0.001 \\
(-0.72)\end{array}$ & $\begin{array}{l}-0.002 \\
(-0.99)\end{array}$ & & $\begin{array}{l}-0.001 \\
(-0.52)\end{array}$ & $\begin{array}{l}-0.002 \\
(-0.77)\end{array}$ \\
\hline $\ln$ Assets & & $\begin{array}{c}0.153^{* * *} \\
(10.39)\end{array}$ & $\begin{array}{l}0.035^{*} \\
(1.70)\end{array}$ & & $\begin{array}{c}0.146^{* * *} \\
(10.05)\end{array}$ & $\begin{array}{l}0.025 \\
(1.22)\end{array}$ \\
\hline Profitability & & $\begin{array}{c}1.153^{* * *} \\
(3.87)\end{array}$ & $\begin{array}{c}0.755^{* *} \\
(2.54)\end{array}$ & & $\begin{array}{c}1.266^{* * *} \\
(4.33)\end{array}$ & $\begin{array}{c}0.858^{* * *} \\
(2.91)\end{array}$ \\
\hline $\mathrm{Q}$ & & $\begin{array}{c}-0.017^{* *} \\
(-2.03)\end{array}$ & $\begin{array}{c}-0.016^{*} \\
(-1.76)\end{array}$ & & $\begin{array}{c}-0.021^{* * *} \\
(-2.66)\end{array}$ & $\begin{array}{c}-0.021^{* *} \\
(-2.38)\end{array}$ \\
\hline Leverage & & $\begin{array}{l}-0.014 \\
(-0.26)\end{array}$ & $\begin{array}{c}-0.160^{* * *} \\
(-2.88)\end{array}$ & & $\begin{array}{l}-0.000 \\
(-0.00)\end{array}$ & $\begin{array}{c}-0.145^{* * *} \\
(-2.61)\end{array}$ \\
\hline CashFlowRisk & & $\begin{array}{c}-0.857^{* *} \\
(-2.28)\end{array}$ & $\begin{array}{c}-0.874^{* *} \\
(-2.26)\end{array}$ & & $\begin{array}{c}-0.830^{* *} \\
(-2.21)\end{array}$ & $\begin{array}{c}-0.855^{* *} \\
(-2.23)\end{array}$ \\
\hline Tangibility & & $\begin{array}{l}0.028 \\
(0.46)\end{array}$ & $\begin{array}{l}0.097 \\
(1.50)\end{array}$ & & $\begin{array}{l}0.035 \\
(0.56)\end{array}$ & $\begin{array}{l}0.101 \\
(1.56)\end{array}$ \\
\hline Syndication & & & $\begin{array}{c}0.146^{* * *} \\
(5.96)\end{array}$ & & & $\begin{array}{c}0.150^{* * *} \\
(6.26)\end{array}$ \\
\hline lnMaturity & & & $\begin{array}{c}0.112^{* * *} \\
(5.82)\end{array}$ & & & $\begin{array}{c}0.111^{* * * *} \\
(5.77)\end{array}$ \\
\hline $\ln A m o u n t$ & & & $\begin{array}{c}0.116^{* * *} \\
(7.23)\end{array}$ & & & $\begin{array}{c}0.118^{* * *} \\
(7.30)\end{array}$ \\
\hline TermLoan & & & $\begin{array}{c}-0.105^{* * *} \\
(-4.42)\end{array}$ & & & $\begin{array}{c}-0.108^{* * *} \\
(-4.55)\end{array}$ \\
\hline Loan Purpose & No & No & Yes & No & No & Yes \\
\hline Industry & Yes & Yes & Yes & Yes & Yes & Yes \\
\hline Year & Yes & Yes & Yes & Yes & Yes & Yes \\
\hline $\begin{array}{l}N \\
\text { pseudo } R^{2}\end{array}$ & $\begin{array}{c}5434 \\
0.0724\end{array}$ & $\begin{array}{c}4429 \\
0.1347\end{array}$ & $\begin{array}{c}4130 \\
0.2061\end{array}$ & $\begin{array}{c}5434 \\
0.0704\end{array}$ & $\begin{array}{c}4429 \\
0.1346\end{array}$ & $\begin{array}{c}4130 \\
0.2060\end{array}$ \\
\hline
\end{tabular}

